Article

\title{
Crambe: Seed Yield and Quality in Response to Nitrogen and Sulfur-A Case Study in Northeastern Poland
}

\author{
Mateusz Sokólski ${ }^{1, *}$, Dariusz Załuski ${ }^{2}$ (D) and Krzysztof Jankowski ${ }^{1}$ (D) \\ 1 Department of Agrotechnology, Agricultural Production Management and Agribusiness, \\ University of Warmia and Mazury in Olsztyn, 10-719 Olsztyn, Poland; krzysztof.jankowski@uwm.edu.pl \\ 2 Department of Plant Breeding and Seed Production, University of Warmia and Mazury in Olsztyn, \\ 10-719 Olsztyn, Poland; dariusz.zaluski@uwm.edu.pl \\ * Correspondence: mateusz.sokolski@uwm.edu.pl; Tel.: +48-89523-33-64
}

Received: 20 August 2020; Accepted: 19 September 2020; Published: 21 September 2020

\begin{abstract}
The aim of this study was to determine the effect of nitrogen $\left(0,30,60,90,120 \mathrm{~kg} \mathrm{ha}^{-1}\right)$ and sulfur $\left(0,15\right.$, and $\left.30 \mathrm{~kg} \mathrm{ha}^{-1}\right)$ fertilization on the morphometric parameters of plants, seed yield components, seed and straw yield, $\mathrm{N}$ fertilizer use efficiency (NFUE), and quality of crambe seeds. The experiment had a randomized complete block design, and it was carried out in Bałcyny (northeastern Poland) in 2017-2019. In northeastern Poland, the average seed yields ranged from 0.96 to $1.64-1.82 \mathrm{Mg} \mathrm{ha}^{-1}$ (hulled seeds). Seed yield increased significantly in response to $120 \mathrm{~kg} \mathrm{~N} \mathrm{ha}^{-1}$ and $15 \mathrm{~kg} \mathrm{~S}^{-1}$. The NFUE of crambe decreased by $28 \%$ with a rise in $\mathrm{N}$ rate. Hulled crambe seeds accumulated $324-394 \mathrm{~g} \mathrm{~kg}^{-1} \mathrm{DM}$ of crude fat, 208-238 $\mathrm{g} \mathrm{kg}^{-1} \mathrm{DM}$ of total protein, and 118-137 $\mathrm{g} \mathrm{kg}^{-1} \mathrm{DM}$ of crude fiber. Nitrogen fertilization decreased the crude fat content (by 6\%), and it increased the total protein content (by 11\%) and the crude fiber content (by 14\%) of crambe seeds. Sulfur fertilization increased crude fat content (by 4-5\%) without inducing significant differences in the total protein content and the crude fat content of seeds.
\end{abstract}

Keywords: Crambe abyssinica; fertilization; seeds and straw yield; fat and protein; fatty acids; fiber

\section{Introduction}

The oil from plants of the family Brassicaceae is a natural source of erucic acid (EA, $\mathrm{C}_{22: 1}$ ), one of very long chain fatty acids (VLCFAs). In plants, VLCFAs and their derivatives are the precursors of suberin, pollen coat, cuticular waxes, and sphingolipids [1]. Erucic acid has numerous industrial applications; it is used in the production of polymers, polyesters, emulsifiers, detergents, ink, paper, cosmetics, pharmaceuticals, textiles, lubricants, food, and fuel [2]. The worldwide consumption of EA increased from 18 to $35 \mathrm{Tg}$ between 1990 and 2010 [3]. The seeds of rapeseed cultivars (Brassica napus var. oleifera L.) with a high content of erucic acid and low concentrations of glucosinolates (high erucic acid rape, HEAR), as well as crambe seeds (Crambe abyssinica Hochst. ex R.E. Fries), are the most popular "green" sources of EA [2,4]. However, the cultivation of HEAR with other rapeseed cultivars (such as low erucic acid rape, LEAR, for food processing) is difficult due to high levels of gene flow mediated by pollen (cross pollination) and seeds (seed shedding during maturation and harvest, and a long period of secondary dormancy) [5,6]. In LEAR production, the risk of EA contamination from HEAR varieties is difficult to control and requires numerous adjustments, including appropriate crop rotations with a low share of Brassica crops, the establishment of buffer zones, and effective control of weeds, in particular of the family Brassicaceae [6]. At present, the oil from C. abyssinica seeds (synonym: Abyssinian oil) is favored over HEAR oil due to a higher content of EA (50-60\% vs. 45-50\%) 
and the absence of the risk of genetic cross-over with edible oilseed crops [7-10]. It should also be noted that only genetically modified HEAR lines have a similar content of $C_{22: 1}$ to $C$. abyssinica $[5,11]$.

Crambe is an annual oilseed crop of the family Brassicaceae. The species originated in the warm-temperate region of eastern Africa (it is endemic to Ethiopia) with moderate rainfall $[10,12,13]$. Crambe had been domesticated in the Mediterranean region, and then it was subsequently adapted to colder and drier regions $[10,12]$. Large-scale production of C. abyssinica probably began in the early 1930s at the Voronez Botanical Station in the former USSR (presently northwestern Russia). In the 1940s, crambe was introduced to the northeastern United States by the Connecticut Agricultural Experiment Station. After World War II, crambe was also introduced to other regions of the USSR as well as to Sweden and Poland [14]. At present, crambe is farmed in several regions of the United States, in tropical and subtropical regions of Africa, Middle East, Central and Western Asia, Europe, and South America [15-18]. According to Von Cossel et al. [19], crambe can be potentially produced on around 52,000 ha of marginal land in the European Union (EU-28), in particular in the Mediterranean mountains, in the northern and southern parts of the Mediterranean region (41\%), as well as in northern and central Atlantic Europe, and in the Lusitanian Basin (34\%). The crop is least suitable for production in Boreal, Continental, Nemoral and Pannonian climate zones [19].

Crambe abyssinica is a winter crop (southern Mediterranean countries and subtropical regions) and a spring-summer crop (northern Europe and regions with a continental climate) [20]. The species easily adapts to varied environmental conditions, and it can be grown in regions with an average annual temperature of $5.7-16.2^{\circ} \mathrm{C}$, annual rainfall of $350-1200 \mathrm{~mm}$, and soil $\mathrm{pH}$ range of 5.0-7.8 [21]. As a result, high seed yields (approximately $3 \mathrm{Mg} \mathrm{ha}^{-1}$ ) can be achieved in highly diverse climates in Europe [14,16,22-25], South America [26-28], North America [29], Asia [17], and Australia [30]. The oil content of crambe seeds is estimated at 260-399 (hulled seeds) and $429-474 \mathrm{~g} \mathrm{~kg}^{-1}$ dry matter (DM) (dehulled seeds) [16-18,26,30-39]. The fatty acid profile of Abyssinian oil is dominated by monounsaturated fatty acids (MUFAs) (75-82\%), including EA (56-63\%). Abyssinian oil contains $12-17 \%$ of polyunsaturated fatty acids (PUFAs) and $4-8 \%$ of saturated fatty acids (SFAs) $[17,18,24,33,34]$. Abyssinian oil has also a high content of phytosterols ( $\beta$-sitosterol, campestanol, and brassicasterol) and $\gamma$-tocopherol [18]. Crambe seeds are a rich source of protein (189-265 $\mathrm{g} \mathrm{kg}^{-1} \mathrm{DM}$ in hulled seeds and $258-312 \mathrm{~g} \mathrm{~kg}^{-1} \mathrm{DM}$ in dehulled seeds) $[17,31-33,36,37]$ with a nutritionally desirable amino acid profile that is similar to that of B. napus [31,40]. The crude fiber content of crambe seeds is $96-180$ (hulled seeds) and 28-103 $\mathrm{g} \mathrm{kg}^{-1} \mathrm{DM}$ (dehulled seeds) [17,33,36,41], including around $25-33 \%$ of neutral detergent fiber (NDF) [33]. Crambe meal can be processed into animal feed and protein isolates [42]. The protein content of defatted crambe meal can reach $250-350$ (hulled seeds) to $371-580 \mathrm{~g} \mathrm{~kg}^{-1} \mathrm{DM}$ (dehulled seeds) [21,42,43]. Crambe seeds contain approximately $72-103 \mu \mathrm{mol} \mathrm{g}{ }^{-1}$ of glucosinolates (GLS), with a predominant share $(90-97 \%)$ of epi-progoitrin [31,33], which considerably limits the use of crambe as a protein source in animal diets [17,22,30,33]. Due to relatively high levels of GLS (mostly alkenyl GLS), crambe meal is highly toxic for monogastric animals [44]. The Food and Drug Administration (a federal agency of the United States Department of Health and Human Services) restricted the use of crambe meal in ruminant feeds to $4.2 \%$ of the total weight of rations [45].

Crambe is known for its desirable agronomic traits such as a short growing season [24,46], tolerance to drought, and adaptability to poor soils in marginal or semiarid land [20], soil salinity, and heavy metal contamination [47]. The species is naturally resistant to insects [48-50], which could be attributed to the high content of GLS [46] that act as natural pesticides against herbivore predation [51]. The cultivars of $C$. abyssinica have a low resistance to pathogens, including Sclerotinia sclerotiorum (Lib) de Bary and fungi of the genus Alternaria, regardless of agroecological conditions [14,38,52-54]. Other potential diseases include blackleg (Leptosphaeria maculans (Desm.) Ces. and de Not.) and root rot (Pythium spp.) [52]. Due to its agronomic traits, crambe can be grown in East-Central Europe, including Poland. In comparison with other parts of Europe, this region is characterized by soils of relatively low quality, low precipitation levels, and limited surface water resources. Crambe is drought-tolerant, which may increase its popularity in East-Central Europe under global warming 
conditions. There is a general scarcity of published data on the effects of crop rotation on crambe cultivation. In a study conducted in the Northern Great Plains, crambe was a less suitable preceding crop for durum wheat (Triticum durum Desf.) than camelina (Camelina sativa (L.) Crantz) and Indian mustard (Brassica juncea (L.) Czern.) [55]. Crambe was not effective in reducing the population of soybean cyst nematodes (SCN) in soils, which suggests that this crop species is not suitable for sustainable management of pathogens in large-area soybean farms in SCN-infested regions [56]. However, due to its short growing cycle, the species could be a highly suitable preceding crop for winter cereals in Europe [46]. In Australia and New Zealand, Brassica crops are more widely used in rotation and intercropping with rice and wheat [57]. The oil and nonfat seed residues of C. abyssinica constitute renewable feedstocks for biofuel and bio-based products in the oleochemical industry $[25,38,58]$.

Brassica crops accumulate large amounts of protein, crude fat, and GLS, and they have a high demand for fertilizers, in particular N. Oils are important plant metabolites with the highest energy density among all carbon reserves [59]. Nitrogen affects the distribution of nutrients to roots and assimilative organs, thus influencing photosynthetic capacity and crop stand productivity [60]. Nitrogen is a part of structural compounds, carriers of energy, and genetic information, as well as compounds that regulate plant metabolism. In Brassica crops, the synthesis of nutrients and biologically active compounds is a highly energy-intensive process, which could explain low $\mathrm{N}$ fertilizer use efficiency (NFUE). In rapeseed, Indian mustard, camelina, field mustard (Brassica rapa L.), white mustard (Sinapis alba L.), and Abyssinian mustard (Brassica carinata A. Braun), NFUE has been determined in the range of 11.1 to $26.4 \mathrm{~kg}$ seed kg-1 $\mathrm{N}$ [61-63]. In B. napus, the highest yielding Brassica crop, NFUE is $27-81 \%$ lower than in common wheat (Triticum aestivum L.) (26 vs. $33-47 \mathrm{~kg}$ seed kg$\left.{ }^{-1} \mathrm{~N}\right)[61,64,65]$. In B. napus, the production of $1 \mathrm{Mg}$ of seeds with the corresponding yield of stems, leaves, and roots requires 50-60 kg N [66]. The remaining Brassica crops, including C. sativa [62,67,68], B. juncea and B. rapa canolas, B. juncea and S. alba mustards [61,69], and S. alba canola [69], have an equally high demand for N. In oilseed crops of the family Brassicaceae, crude fat content is the most important quality trait which is negatively correlated with total protein content $[70,71]$. Nitrogen decreases the content of crude fat and increases the total protein content of seeds in Brassica crops [68,72,73]. A negative correlation between $\mathrm{N}$ fertilization and the oil and protein content of seeds is not observed only when $\mathrm{N}$ does not exert yield-forming effects [63].

Brassica oilseed crops need 15-20 kg S to produce $1 \mathrm{Mg}^{-1}$ seeds and the corresponding straw yield [74]. Sulfur is present in selected amino acids and glutathione, which are responsible for the structure of the protein chain [75]. Compounds containing sulfhydryl groups (-SH) participate in redox reactions [76] and determine the activity of many enzymes. Sulfur is also found in sulfolipids, the structural elements of cell membranes [77]. Brassicaceae crops have a high demand for $\mathrm{S}$ that participates in the biosynthesis of GLS [78]. All GLS contain S and glucose, but they differ in the structure of aglycone, which determines the compound's properties [79]. The effect of $S$ fertilization on the metabolism of Brassica plants, including the content of essential nutrients, varies depending on $\mathrm{SO}_{4}^{2-}$ levels in soil, atmospheric deposition of $\mathrm{S}$, the biological activity of soil which affects the transformation rates of $S$, and agronomic factors [80]. In recent years, $S$ has emerged as an important fertilizer due to the progressive depletion of $\mathrm{S}$ from soils, increasing production of Brassica crops in agricultural ecosystems, and a significant decrease in annual $\mathrm{SO}_{2}$ deposition in soils [81]. In Poland, the annual $\mathrm{SO}_{2}$ emissions to ambient air have decreased nearly five-fold ( 2.53 vs. 0.56 million $\mathrm{Mg}$ ) in the past 27 years (1990-2017) [82]. In crops of the family Brassicaceae, S fertilizers not only increase yields, but also influence the quality of agricultural products, including oil, fat-free seed residues, and harvest residues [81,83-85]. Sulfur fertilization is much more likely to affect total protein concentration than crude fat concentration in the seeds of Brassica oilseed crops [86] because $\mathrm{S}$ actively participates in the synthesis of major S-containing amino acids (cysteine and methionine) [87].

The aim of this study was to determine the effect of $\mathrm{N}$ and $\mathrm{S}$ fertilization on plant parameters (plant height, shoot diameter at the base, number of productive branches), yield (seed yield, yield components, straw yield, harvest index), and the processing suitability of crambe seeds as 
a potential feedstock for bio-based products in the oleochemical industry (content of crude fat, total protein, crude fiber, fatty acids, acid detergent fiber (ADF) and NDF) in northeastern Poland.

\section{Materials and Methods}

\subsection{Field Experiment}

Crambe (Crambe abyssinica Hochst. ex R.E. Fries) was grown in the Agricultural Experiment

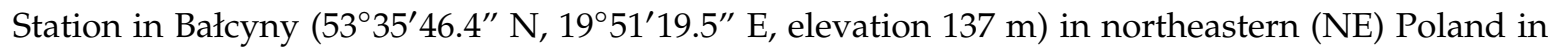
2017-2019. The station is part of the University of Warmia and Mazury in Olsztyn. The experimental variables were (i) $\mathrm{N}$ rate $\left(\mathrm{kg} \mathrm{ha}^{-1}\right)$ 0, 30, 60, 90, 120 and (ii) $\mathrm{S}$ rate $\left(\mathrm{kg} \mathrm{ha}^{-1}\right)$ 0, 15, 30. A single rate of $\mathrm{N}$ was applied immediately before sowing at up to $90 \mathrm{~kg} \mathrm{ha}^{-1}$. Higher $\mathrm{N}$ rates $\left(120 \mathrm{~kg} \mathrm{ha}^{-1}\right)$ were split into two doses: $90 \mathrm{~kg} \mathrm{~N}$ ha $^{-1}$ immediately before sowing and $30 \mathrm{~kg} \mathrm{~N} \mathrm{ha}^{-1}$ in BBCH stages 22-23 (identification key for growth stages [88]). Nitrogen was applied as ammonium nitrate (34\% N). Sulfur was applied as potassium sulfate $\left(18 \% \mathrm{~S}, 50 \% \mathrm{~K}_{2} \mathrm{O}\right)$ immediately before sowing.

The experiment had a randomized complete block design (RCB) with three replications. Plot size was $15 \mathrm{~m}^{2}$ (10 by $1.5 \mathrm{~m}$ ). In each year of the study, the preceding crop was spring wheat (Triticum aestivum L.). The applied tillage treatments were skimming, winter plowing, and soil loosening before sowing. Crambe cv. Borowski was sown at the beginning of April (9-11 April) with a plot seeder at 200 pure live seeds $\mathrm{m}^{-2}$, with a spacing of $19 \mathrm{~cm}$, to a depth of 1.5-2.0 cm. Directly before sowing, phosphorus (enriched superphosphate, $40 \% \mathrm{P}_{2} \mathrm{O}_{5}$ ) was applied at $40 \mathrm{~kg} \mathrm{ha}^{-1} \mathrm{P}_{2} \mathrm{O}_{5}$, and potassium (potassium sulfate, $50 \% \mathrm{~K}_{2} \mathrm{O}$, and/or potash salt, $60 \% \mathrm{~K}_{2} \mathrm{O}$ ) was applied at $100 \mathrm{~kg} \mathrm{ha}^{-1} \mathrm{~K}_{2} \mathrm{O}$. Weeds were controlled with metazachlor, which was applied at $1000 \mathrm{~g} \mathrm{ha}^{-1}$ immediately after sowing. Pesticide ( $6 \mathrm{~g} \mathrm{ha}^{-1}$ lambda-cyhalothrin) was applied at the beginning of inflorescence emergence (50 BBCH). Crambe was harvested at physiological maturity (89 BBCH) using a small-plot harvester (5-29 August).

The experiment was established on Haplic Luvisol originating from boulder clay [89]. The chemical properties of the soil are presented in the Table 1.

Table 1. Chemical properties of the analyzed soil.

\begin{tabular}{|c|c|c|c|c|c|c|}
\hline \multirow{2}{*}{ Years } & \multirow{2}{*}{$\mathrm{pH}^{\mathrm{a}}$} & \multirow{2}{*}{$C_{\text {org }}\left(g_{k^{-1}}\right)^{b}$} & \multicolumn{4}{|c|}{ Available Macronutrients $\left(\mathrm{mg} \mathrm{kg}^{-1}\right)^{\mathrm{c}}$} \\
\hline & & & $\mathbf{P}$ & $\mathbf{K}$ & Mg & $\mathrm{SO}_{4}^{2-}$ \\
\hline 2017 & 6.2 & 1.10 & 42.1 & 157.7 & 72.0 & 12.5 \\
\hline 2018 & 6.0 & 1.25 & 37.5 & 145.2 & 81.0 & 11.7 \\
\hline 2019 & 6.0 & 1.05 & 59.3 & 108.1 & 60.0 & 13.3 \\
\hline
\end{tabular}

\footnotetext{
a digital $\mathrm{pH}$ meter with temperature compensation $\left(20^{\circ} \mathrm{C}\right)$ in deionized water and $1 \mathrm{~mol} \mathrm{dm}^{-3} \mathrm{KCl}$, at a $5: 1$ ratio. ${ }^{\mathrm{b}}$ modified Kurmies method (UV-1201V spectrophotometer, Shimadzu Corporation, Kyoto, Japan). ${ }^{\mathrm{c}} \mathrm{P}$ —vanadium molybdate yellow colorimetric method (UV-1201V spectrophotometer, Shimadzu Corporation, Kyoto, Japan); $\mathrm{K}$-atomic emission spectrometry (AES) (Flame Photometers, BWB Technologies Ltd., Newbury, UK); Mg—atomic absorption spectrophotometry (AAS) (AAS1N, Carl Zeiss Jena, Germany); and $\mathrm{SO}_{4}^{2-}$-nephelometry method (UV-1201V spectrophotometer, Shimadzu Corporation, Kyoto, Japan).
}

\subsection{Plant Materials}

The biomass yield of crambe (hulled seeds and straw) from each plot was determined by weight after threshing and expressed in DM per hectare, taking into account the moisture content of samples after oven-drying at $105^{\circ} \mathrm{C}$. The main morphometric parameters (plant height, shoot diameter at the base, number of productive branches) and yield components (plants $\mathrm{m}^{-2}$ and hulled seeds plant ${ }^{-1}$ ) were determined immediately before harvest $(89 \mathrm{BBCH})$. Plants were counted (plant $\mathrm{m}^{-2}$ and morphometric parameters) along a 1-m-long section of each of the two middle rows [90]. The number of hulled seeds plant ${ }^{-1}$ was calculated as the ratio between hulled seed yield and hulled seed weight [24]. Thousand hulled seed weight (TSW) was determined after harvest and expressed on a DM basis, 
taking into account the moisture content of samples after oven-drying at $105^{\circ} \mathrm{C}$. The harvest index (HI) was calculated using Equation (1):

$$
\mathrm{HI}=\frac{\text { Seed yield }\left(\mathrm{Mg} \mathrm{DM} \mathrm{ha}^{-1}\right)}{\text { Seed and straw yield }\left(\mathrm{Mg} \mathrm{DM} \mathrm{ha}^{-1}\right)}
$$

Nitrogen fertilizer use efficiency (NFUE) was calculated with Equation (2) [61]:

$$
\mathrm{NFUE}=\frac{\text { Hulled seed yield in } \mathrm{N} \text { treatments }\left(\mathrm{kg} \mathrm{ha}^{-1}\right)-\text { Hulled seed yield without } \mathrm{N}\left(\mathrm{kg} \mathrm{ha}^{-1}\right)}{\left.\mathrm{N} \text { rate } \mathrm{kg} \mathrm{ha}^{-1}\right)}
$$

Hulled seed samples were scanned in the NIR Systems 6500 monochromator (FOSS NIR Systems Inc., Laurel, MD, USA) equipped with a reflectance module. Intact seeds (approximately $5 \mathrm{~g}$ ) were placed in a standard ring cup and scanned. The content of total protein, crude fat, crude fiber, ADF, and NDF in crambe seeds, and the fatty acid composition of Abyssinian oil, were determined according to the procedures described by Jankowski et al. [68].

\subsection{Statistical Analysis}

Data were analyzed in the general linear mixed model in Statistica software [91] with $\mathrm{N}$ and S fertilizers as the fixed effects, and the growing season $(\mathrm{Y})$ and replications nested within years as the random effects. Post hoc multiple comparisons were performed with the use of Tukey's test (HSD) in subsequent stages of statistical analyses. Data were regarded as statistically significant at $\alpha=0.05$. The results of the F-test for fixed effects in ANOVA are presented in Table 2.

\begin{tabular}{|c|c|c|c|c|c|c|c|}
\hline Trait & $\mathbf{Y}$ & $\mathbf{N}$ & $\mathbf{S}$ & $\mathbf{Y} \times \mathbf{N}$ & $\mathbf{Y} \times \mathbf{S}$ & $\mathbf{N} \times \mathbf{S}$ & $\mathbf{Y} \times \mathbf{N} \times \mathbf{S}$ \\
\hline Plant height $(\mathrm{cm})$ & $459.71 * *$ & $8.01^{* *}$ & $2.77 n s$ & $1.7 n s$ & $2.47 n s$ & $0.54 n s$ & $0.34 n s$ \\
\hline Shoot diameter at base $(\mathrm{mm})$ & $59.91 * *$ & $25.07 * *$ & $1.86 n s$ & $4.09 * *$ & $0.56 n s$ & $1.66 n s$ & $0.62 n s$ \\
\hline Number of branches & $47.53 * *$ & $15.43 * *$ & $0.79 n s$ & $1.28 n s$ & $0.60 n s$ & $0.26 n s$ & $0.07 n s$ \\
\hline Plants $\mathrm{m}^{-2}$ & $151.17 * *$ & $4.23^{* *}$ & $0.56 n s$ & $1.28 n s$ & $0.79 n s$ & $0.14 n s$ & $0.13 n s$ \\
\hline Seeds plant ${ }^{-1}$ & $49.17^{* *}$ & $12.59 * *$ & $2.25 n s$ & $5.47^{* *}$ & $0.21 n s$ & $0.36 n s$ & $0.37 n s$ \\
\hline TSW $(g)$ & $22.57 * *$ & $1.16 n s$ & $16.27^{* *}$ & $4.90 * *$ & $2.13 n s$ & $0.95 n s$ & $0.30 n s$ \\
\hline Seed yield $\left(\mathrm{Mg} \mathrm{ha}^{-1}\right)$ & $273.58 * *$ & $26.20 * *$ & $9.17^{* *}$ & $4.47^{* *}$ & $0.53 n s$ & $0.74 n s$ & $0.31 n s$ \\
\hline NFUE $\left(\mathrm{kg}\right.$ seed $\left.\mathrm{kg}^{-1} \mathrm{~N}\right)$ & $7.91 * *$ & $3.61 n s$ & $0.31 n s$ & $1.65 n s$ & $0.29 n s$ & 0.79 ns & $0.30 n s$ \\
\hline Straw yield $\left(\mathrm{Mg} \mathrm{ha}^{-1}\right)$ & $313.05^{* *}$ & $10.51^{* *}$ & $5.28 * *$ & $1.13 n s$ & 0.51 ns & 0.59 ns & 0.55 ns \\
\hline Harvest index & $79.53 * *$ & $1.57 n s$ & $1.36 n s$ & $2.42 *$ & $0.62 n s$ & $0.64 n s$ & $0.29 n s$ \\
\hline $\begin{array}{l}\text { Crude fat content } \\
\left(\mathrm{g} \mathrm{kg}^{-1} \mathrm{DM}\right)\end{array}$ & $111.64^{* *}$ & $4.14^{* *}$ & $5.00^{* *}$ & $1.24 n s$ & $4.05^{* *}$ & 1.23 ns & $0.84 n s$ \\
\hline $\mathrm{C}_{16}(\%)$ & $3.30 *$ & $3.56^{* *}$ & $0.69 n s$ & $1.77 n s$ & $0.21 n s$ & $0.86 n s$ & $1.42 n s$ \\
\hline $\mathrm{C}_{18}(\%)$ & $0.57 n s$ & $0.31 n s$ & $0.85 n s$ & $1.21 \mathrm{~ns}$ & $0.37 n s$ & $0.35 n s$ & $0.52 n s$ \\
\hline $\mathrm{C}_{18: 1}(\%)$ & $7.17^{* *}$ & 0.05 ns & 0.06 ns & $0.16 \mathrm{~ns}$ & $0.04 n s$ & $0.02 n s$ & 0.05 ns \\
\hline $\mathrm{C}_{18: 2}(\%)$ & $135.94 * *$ & $4.50 *$ & $2.93 *$ & $2.03 n s$ & $1.27 n s$ & 1.09 ns & $1.09 \mathrm{~ns}$ \\
\hline $\mathrm{C}_{18: 3}(\%)$ & $6.44^{* *}$ & $2.61 *$ & $0.31 n s$ & $0.61 n s$ & $1.10 \mathrm{~ns}$ & $0.92 n s$ & $0.68 n s$ \\
\hline $\mathrm{C}_{20: 1}(\%)$ & $56.90 * *$ & $0.06 n s$ & $0.26 n s$ & $0.23 n s$ & $0.28 n s$ & $0.05 n s$ & $0.22 n s$ \\
\hline $\mathrm{C}_{22: 1}(\%)$ & $20.71 * *$ & $0.07 n s$ & 0.10 ns & $0.20 n s$ & $0.14 n s$ & $0.20 n s$ & $0.18 n s$ \\
\hline SFAs (\%) & $2.98 n s$ & $1.63 n s$ & $0.38 n s$ & $0.50 \mathrm{~ns}$ & $0.27 n s$ & $0.97 n s$ & $1.72 n s$ \\
\hline MUFAs (\%) & $6.83^{* *}$ & $0.15 n s$ & $0.01 n s$ & $0.33 n s$ & $0.17 n s$ & $0.34 n s$ & $0.20 n s$ \\
\hline PUFAs (\%) & $6.52 * *$ & $0.03 n s$ & $0.01 n s$ & $0.10 n s$ & $0.12 n s$ & $0.22 n s$ & $0.07 n s$ \\
\hline Total protein content $\left(\mathrm{g} \mathrm{kg}^{-1} \mathrm{DM}\right)$ & $44.59 * *$ & $9.25^{* *}$ & $2.97 n s$ & $6.64 * *$ & $0.66 n s$ & $0.85 n s$ & 0.70 ns \\
\hline Crude fiber content ( $\left.\mathrm{g} \mathrm{kg}^{-1} \mathrm{DM}\right)$ & $11.68 * *$ & $3.78^{* *}$ & $1.06 n s$ & $0.29 n s$ & $1.55 n s$ & $1.27 n s$ & $0.79 n s$ \\
\hline $\operatorname{NDF}(\%)$ & $55.11 * *$ & $4.95^{* *}$ & $0.48 n s$ & $1.57 n s$ & $0.23 n s$ & $0.60 n s$ & $0.48 n s$ \\
\hline $\operatorname{ADF}(\%)$ & $0.00 n s$ & $1.78 n s$ & $0.10 n s$ & $1.01 \mathrm{~ns}$ & $0.28 n s$ & $0.62 n s$ & $0.34 n s$ \\
\hline
\end{tabular}

Table 2. F-test statistics in ANOVA.

* significant $p<0.05 ;{ }^{* *}$ significant $p<0.01 ; n s-$ not significant. Y-growing season; N-nitrogen fertilization; S-sulfur fertilization; TSW-1000-seed weight; NFUE-nitrogen fertilizer use efficiency; $\mathrm{C}_{16}$ - palmitic acid; $\mathrm{C}_{18}$ - stearic acid; $\mathrm{C}_{18: 1}$ —oleic acid; $\mathrm{C}_{18: 2}$ - linoleic acid; $\mathrm{C}_{18: 3}$-linolenic acid; $\mathrm{C}_{20: 1}$ —eicosanoic acid; $\mathrm{C}_{22: 1}$-erucic acid; SFA — saturated fatty acids; MUFA — monounsaturated fatty acids; PUFA—polyunsaturated fatty acids; ADF—acid detergent fiber; NDF-neutral detergent fiber. 


\section{Results}

\subsection{Weather Condition}

The growing seasons (April-August) during the field experiment differed in temperature and precipitation levels (Figure 1). In the first growing season, the average daily temperature approximated the long-term average (1981-2015). In the second growing season, the average daily temperature exceeded the long-term average. In the third growing season, the average daily temperature was similar to the long-term average, excluding June when this parameter exceeded the long-term average. Total rainfall in March-August was $264 \mathrm{~mm}$ in 2017, $331 \mathrm{~mm}$ in 2018, and $371 \mathrm{~mm}$ in 2019. At the experimental site, the average long-term precipitation during the growing season over the last 37 years (in 1981-2015) reached $342 \mathrm{~mm}$. The first growing season was characterized by low total precipitation due to rainfall deficiency in May, July, and August (59, 65, and 31\% of the long-term average, respectively). In the second growing season, rainfall levels approximated the long-term average (1981-2015). In the third year of the study, the wet months of May and June (with precipitation levels $66 \%$ and $28 \%$ higher than the long-term average, respectively) contributed to above-average precipitation levels during the entire growing season (March-August) (Figure 1).

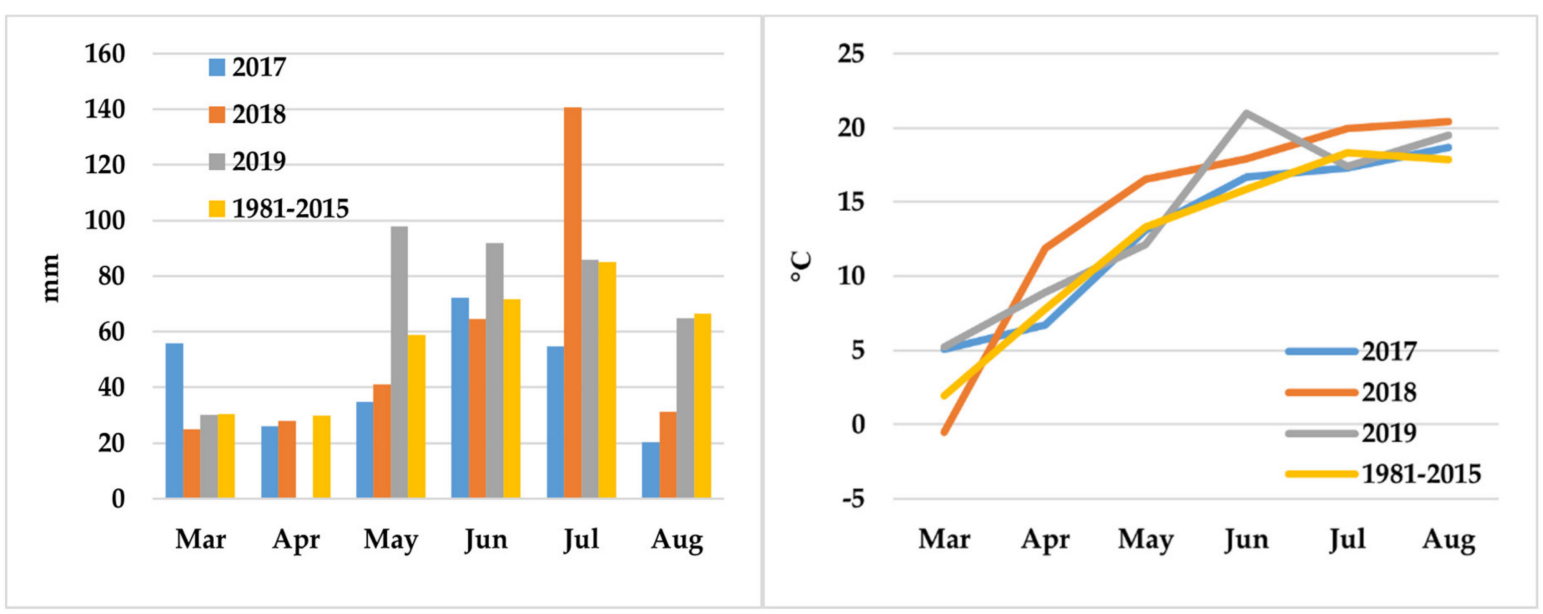

Figure 1. Total monthly rainfall $(\mathrm{mm})$ and average monthly temperature $\left({ }^{\circ} \mathrm{C}\right)$ during the growing season of crambe in 2017-2019 and the long-term average (1981-2015) at the experimental site.

\subsection{Plant Height}

Crambe plants produced shoots with a length of $65-103 \mathrm{~cm}$, base diameter of 5-6 mm, and 7-8 productive branches (Table 3). The vegetative growth rate of $C$. abyssinica was highest in the third year of the study (Table 3) when precipitation levels exceeded the long-term average in May and June (Figure 1).

Table 3. Selected morphometric properties of crambe plants.

\begin{tabular}{cccc}
\hline \multicolumn{1}{c}{ Parameter } & Plant Height $(\mathbf{c m})$ & Shoot Diameter at Base $(\mathbf{m m})$ & Number of Branches \\
\hline Year & & & \\
& $65.0^{\mathrm{c}}$ & $5.4^{\mathrm{b}}$ & $6.8^{\mathrm{c}}$ \\
2017 & $69.2^{\mathrm{b}}$ & $5.4^{\mathrm{b}}$ & $7.4^{\mathrm{b}}$ \\
2019 & $103.4^{\mathrm{a}}$ & $6.4^{\mathrm{a}}$ & $8.5^{\mathrm{a}}$ \\
\multicolumn{2}{c}{ Nitrogen rate $\left(\mathrm{kg} \mathrm{ha}^{-1}\right)$, across years } & & \\
0 & $73.4^{\mathrm{b}}$ & $5.0^{\mathrm{c}}$ & $6.5^{\mathrm{c}}$ \\
30 & $79.3^{\mathrm{a}}$ & $5.5^{\mathrm{b}}$ & $7.6^{\mathrm{b}}$ \\
60 & $79.2^{\mathrm{a}}$ & $6.0^{\mathrm{ab}}$ & $7.7^{\mathrm{ab}}$ \\
90 & $81.2^{\mathrm{a}}$ & $6.0^{\mathrm{a}}$ & $7.8^{\mathrm{ab}}$ \\
120 & $83.0^{\mathrm{a}}$ & $6.3^{\mathrm{a}}$ & $8.2^{\mathrm{a}}$ \\
\hline
\end{tabular}


Table 3. Cont.

\begin{tabular}{cccc}
\hline Parameter & Plant Height $(\mathbf{c m})$ & Shoot Diameter at Base $(\mathbf{m m})$ & Number of Branches \\
\hline Sulfur rate $\left(\mathrm{kg} \mathrm{ha}^{-1}\right)$, across years & & & \\
0 & 77.4 & 5.6 & 7.4 \\
15 & 80.6 & 5.7 & 7.6 \\
30 & 79.5 & 5.9 & 7.7 \\
\hline
\end{tabular}

Means with the same letters do not differ significantly at $p \leq 0.05$ in Tukey's test. The absence of superscript letters indicates that the main effects or interactions were not statistically significant.

Nitrogen fertilization stimulated the vegetative growth of crambe. Crambe plants fertilized with $\mathrm{N}$ produced significantly taller (by $10 \%$ ) and thicker shoots (by $20 \%$ ) with more productive branches (by $26 \%$ ) relative to the control treatment (without $\mathrm{N}$ fertilization). Nitrogen stimulated the vegetative growth of C. abyssinica up to the rate of 30 taller shoots, 90 thicker shoots, and $120 \mathrm{~kg} \mathrm{ha}^{-1}$ higher number of productive branches. Nitrogen had no beneficial influence on shoot thickness except in the dry year of 2017, in particular during seed setting and filling (July and August) (Figure 2). Sulfur fertilization did not induce significant differences in the vegetative growth rate of C. abyssinica (Table 3).

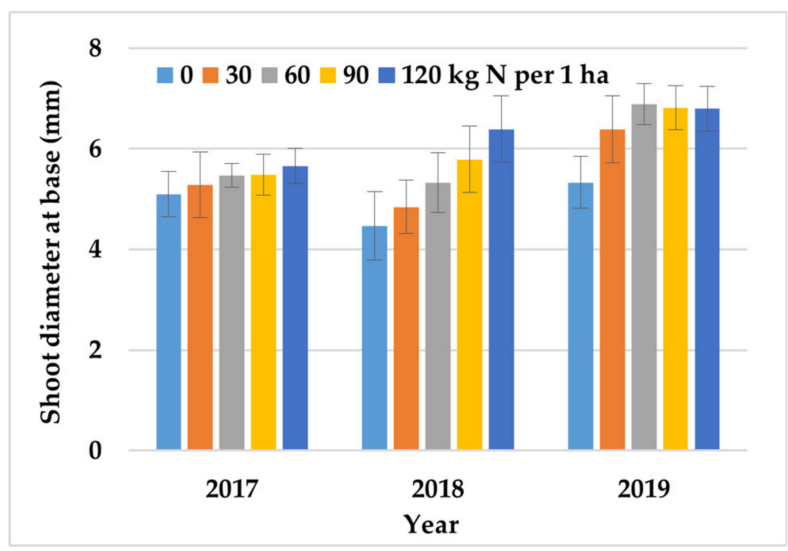

Figure 2. The effect of $\mathrm{N}$ fertilization on the shoot diameter of crambe plants across growing seasons (2017-2019). Error bars represent the standard deviation.

\subsection{Yield Components}

The density of $C$. abyssinica stands before harvest ranged from $129(2017)$ to $162-166(2018,2019)$ plants $\mathrm{m}^{-2}$. In NE Poland, crambe produced 94 do 131 seeds plant ${ }^{-1}$ with TSW (hulled seeds) of 8.0 to $8.7 \mathrm{~g}$ (Table 4). Yield components were most favorable in the third year of the study that was characterized by above-average precipitation in the growing season. Yield components were least expressed in the dry year of 2017 (first year of the experiment). Water-stressed plants were characterized by lower density (by $21 \%$ ) and set significantly fewer seeds (by $28 \%$ ) with lower TSW (by $8 \%$ ) (Table 4).

Table 4. Yield components and biomass yield of crambe.

\begin{tabular}{|c|c|c|c|c|c|c|c|}
\hline Parameter & Plants $\mathrm{m}^{-2}$ & Seeds plant ${ }^{-1}$ & TSW (g) & $\begin{array}{l}\text { Seed Yield } \\
\left(\mathrm{Mg} \mathrm{ha}^{-1}\right)\end{array}$ & $\begin{array}{c}\text { NFUE } \\
\left(\mathrm{kg} \mathrm{seeds} \mathrm{kg}^{-1} \mathrm{~N}\right)\end{array}$ & $\begin{array}{c}\text { Straw Yield } \\
\left(\mathrm{Mg} \mathrm{ha}^{-1}\right)\end{array}$ & $\begin{array}{c}\text { Harvest } \\
\text { Index }\end{array}$ \\
\hline \multicolumn{8}{|l|}{ Year } \\
\hline 2017 & $129^{b}$ & $94.0^{c}$ & $8.0^{c}$ & $0.96^{c}$ & $2.09^{b}$ & $1.24^{\mathrm{c}}$ & $0.43^{b}$ \\
\hline 2018 & $166^{\mathrm{a}}$ & $121.0^{\mathrm{b}}$ & $8.3^{\mathrm{b}}$ & $1.64^{\mathrm{b}}$ & $5.63^{\mathrm{a}}$ & $1.80^{\mathrm{b}}$ & $0.48^{\text {a }}$ \\
\hline 2019 & $162^{\mathrm{a}}$ & $131.1^{\mathrm{a}}$ & $8.7^{\mathrm{a}}$ & $1.82^{\mathrm{a}}$ & 5.89 a & $3.40^{\mathrm{a}}$ & $0.35^{c}$ \\
\hline \multicolumn{8}{|c|}{ Nitrogen rate $\left(\mathrm{kg} \mathrm{ha}^{-1}\right)$, across years } \\
\hline 0 & $145^{b \prime}$ & $99.6^{c}$ & 8.4 & $1.22 \mathrm{~d}$ & - & $1.90^{\mathrm{c}}$ & 0.41 \\
\hline 30 & $154^{\text {a }}$ & $105.7^{b c}$ & 8.3 & $1.38^{\mathrm{c}}$ & 5.27 & $1.88^{\mathrm{c}}$ & 0.44 \\
\hline 60 & $153^{a}$ & $117.7^{\mathrm{ab}}$ & 8.3 & $1.51^{\mathrm{bc}}$ & 4.94 & $2.15^{b c}$ & 0.42 \\
\hline 90 & $155^{\mathrm{a}}$ & $124.1^{\mathrm{a}}$ & 8.2 & $1.59 \mathrm{ab}$ & 4.14 & 2.28 ab & 0.42 \\
\hline 120 & $155^{\mathrm{a}}$ & $129.6^{\mathrm{a}}$ & 8.4 & $1.67^{\mathrm{a}}$ & 3.80 & $2.52^{\mathrm{a}}$ & 0.42 \\
\hline
\end{tabular}


Table 4. Cont.

\begin{tabular}{|c|c|c|c|c|c|c|c|}
\hline Parameter & Plants $\mathrm{m}^{-2}$ & Seeds plant ${ }^{-1}$ & TSW (g) & $\begin{array}{l}\text { Seed Yield } \\
\left(\mathrm{Mg} \mathrm{ha}^{-1}\right)\end{array}$ & $\begin{array}{c}\text { NFUE } \\
\left(\mathrm{kg} \text { seeds kg }{ }^{-1} \mathrm{~N}\right)\end{array}$ & $\begin{array}{l}\text { Straw Yield } \\
\left(\mathrm{Mg} \mathrm{ha}^{-1}\right)\end{array}$ & $\begin{array}{c}\text { Harvest } \\
\text { Index }\end{array}$ \\
\hline \multicolumn{8}{|c|}{ Sulfur rate $\left(\mathrm{kg} \mathrm{ha}^{-1}\right)$, across years } \\
\hline 0 & 151 & 111.1 & $8.1^{\mathrm{b}}$ & $1.38^{\mathrm{b}}$ & 4.62 & $2.02^{b}$ & 0.42 \\
\hline 15 & 153 & 119.3 & $8.1^{\mathrm{b}}$ & $1.50^{\mathrm{a}}$ & 4.08 & $2.11^{\mathrm{ab}}$ & 0.43 \\
\hline 30 & 152 & 115.6 & $8.7^{\mathrm{a}}$ & $1.54^{\mathrm{a}}$ & 4.91 & $2.31^{\mathrm{a}}$ & 0.41 \\
\hline
\end{tabular}

Means with the same letters do not differ significantly at $p \leq 0.05$ in Tukey's test. The absence of superscript letters indicates that the main effects or interactions were not statistically significant. TSW-1000-seed weight; NFUE-nitrogen fertilizer use efficiency.

Nitrogen fertilization increased plant density before harvest (by 6\%) and the number of seeds plant $^{-1}$ (by 25\%) (Table 4). Nitrogen exerted a positive effect on plant density and the number of seeds plant ${ }^{-1}$, up to the rate of 30 and $90 \mathrm{~kg} \mathrm{ha}^{-1}$, respectively. An interaction was found between $\mathrm{N}$ fertilization and weather conditions for the number of seeds plant $^{-1}$ and TSW (Table 2). In the growing season characterized by high yields (high precipitation in the third year of the experiment), an increase in $\mathrm{N}$ rate to $120 \mathrm{~kg} \mathrm{ha}^{-1}$ led to a 1.7-fold increase in the number of seeds plant ${ }^{-1}$ accompanied by a $12 \%$ decrease in TSW (Figure 3). In the year with average precipitation (2018), the number of seeds plant ${ }^{-1}$ increased by $16 \%$ in response to the $\mathrm{N}$ rate of up to $60 \mathrm{~kg} \mathrm{~N} \mathrm{ha}^{-1}$. In the driest year of 2017, N fertilization had no significant effect on the number of seeds plant ${ }^{-1}$ (Figure 3).

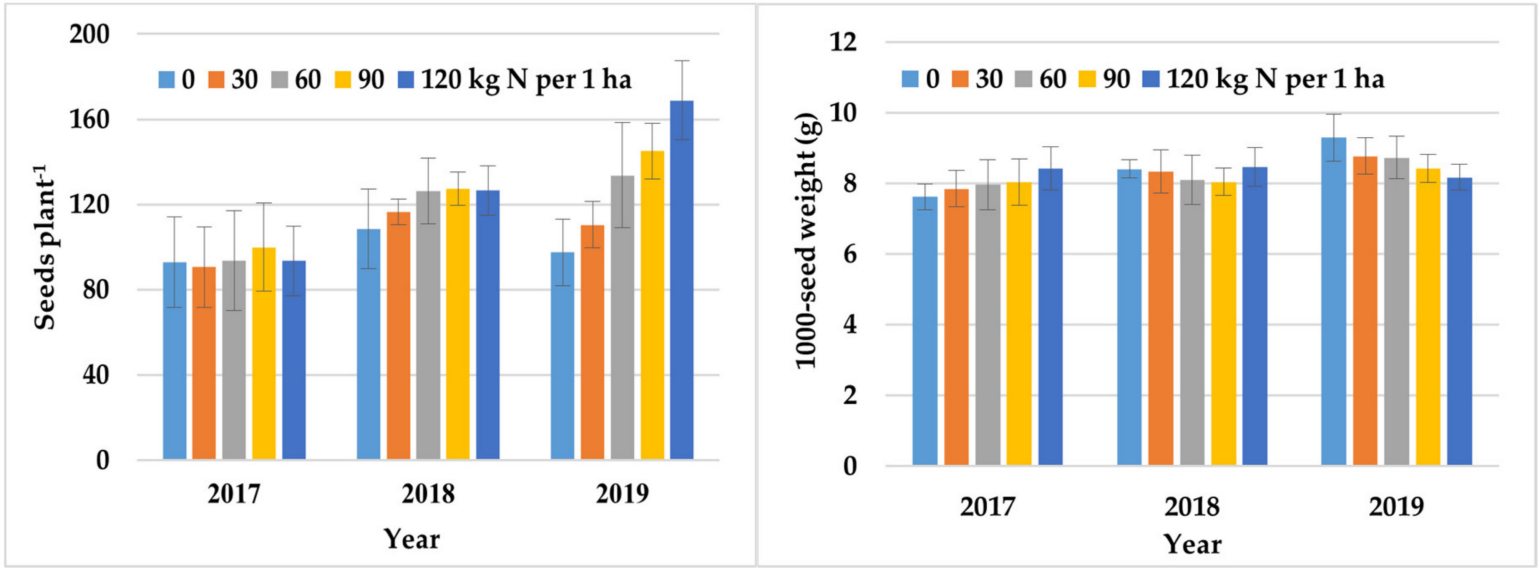

Figure 3. The effect of $\mathrm{N}$ fertilization on the number of seeds plant ${ }^{-1}$ and 1000 -seed weight of crambe across growing seasons (2017-2019). Error bars represent the standard deviation.

Thousand-seed weight increased by $6 \%$ in response to the $S$ fertilization rate of up to $30 \mathrm{~kg} \mathrm{ha}^{-1}$ (Table 4), regardless of agroecological conditions or $\mathrm{N}$ rate (Table 2). The remaining yield components (plants $\mathrm{m}^{-2}$ and seeds plant $^{-1}$ ) were not significantly affected by $\mathrm{S}$ fertilization (Table 2).

\subsection{Biomass Yield and Harvest Index}

In NE Poland, the average seed yield of crambe ranged from 0.96 to $1.64-1.82 \mathrm{Mg} \mathrm{ha}^{-1}$ (hulled seeds). Nitrogen rates up to $120 \mathrm{~kg} \mathrm{ha}^{-1}$ contributed to a significant increase in seed yield (by $0.45 \mathrm{Mg} \mathrm{ha}^{-1}$ ), mainly due to the beneficial influence of $\mathrm{N}$ on the number of plants $\mathrm{m}^{-2}$ and seeds plant ${ }^{-1}$ (Table 4 ). Nitrogen rates up to $120 \mathrm{~kg} \mathrm{ha}^{-1}$ improved yields (Figure 4) in years with average and above-average precipitation during the growing season of $C$. abyssinica $(2018,2019)$. In the year with below-average precipitation (2017), N rates of 30-120 kg ha-1 were not productive (Figure 4). Sulfur rates up to $15 \mathrm{~kg} \mathrm{ha}^{-1}$ induced a significant increase in seed yield (by $0.12 \mathrm{Mg} \mathrm{ha}^{-1}$, i.e., $9 \%$ ) relative to the unfertilized control (Table 4), regardless of agroecological conditions or $\mathrm{N}$ rate (Table 2). 


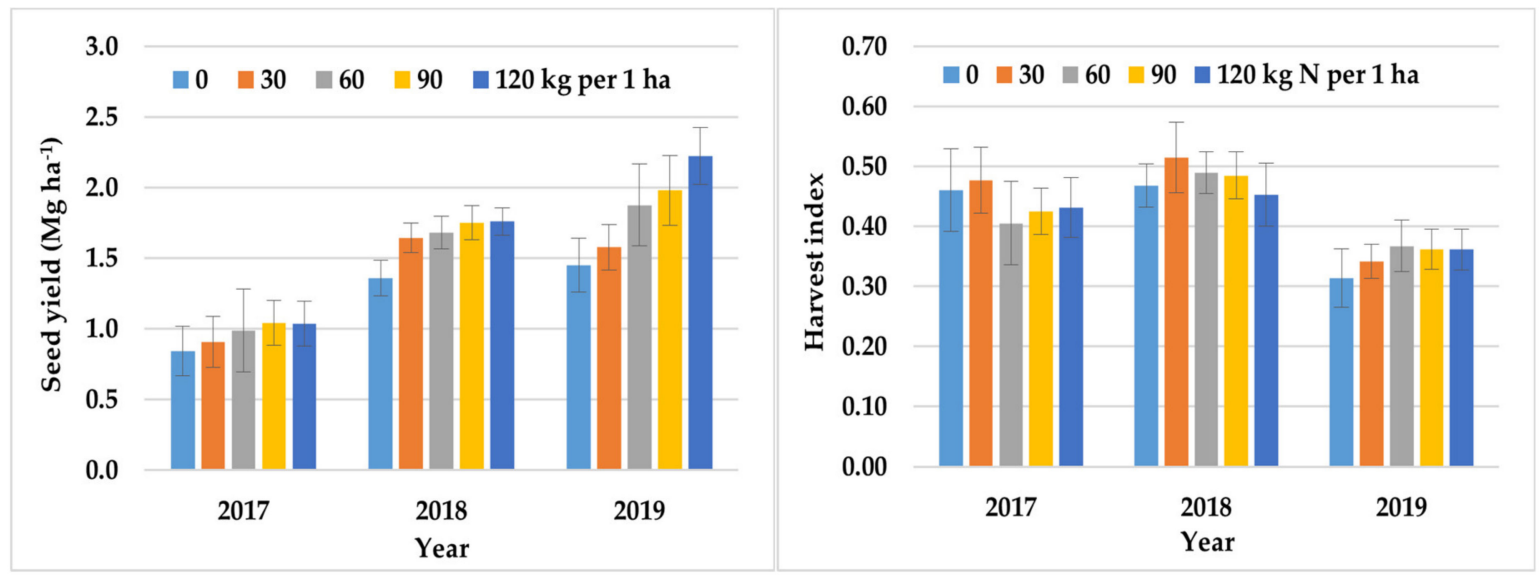

Figure 4. The effect of $\mathrm{N}$ fertilization on crambe seed yields and harvest index across growing seasons (2017-2019). Error bars represent the standard deviation.

The NFUE of crambe ranged from 2.1 (2017) to $5.6-5.9 \mathrm{~kg}$ of hulled seeds $\mathrm{kg}^{-1} \mathrm{~N}(2018,2019)$. An increase in $\mathrm{N}$ rate from 30 to $120 \mathrm{~kg} \mathrm{~N}^{-1}$ decreased NFUE by $28 \%$ on average (Table 4), regardless of agroecological conditions (Table 2). It should be noted that $\mathrm{S}$ fertilization increased the efficiency of $\mathrm{N}$ rates of $\geq 30 \mathrm{~kg} \mathrm{ha}^{-1}$ by $29-39 \%\left(60 \mathrm{~kg} \mathrm{~N} \mathrm{ha}^{-1}\right), 23-31 \%\left(90 \mathrm{~kg} \mathrm{~N} \mathrm{ha}^{-1}\right)$, and $22 \%\left(120 \mathrm{~kg} \mathrm{~N} \mathrm{ha}^{-1}\right)$ (Figure 5). In treatments with low $\mathrm{N}$ fertilization levels $\left(30 \mathrm{~kg} \mathrm{ha}^{-1}\right)$, the application of $\mathrm{S}$ caused a 1.7to 2.1-fold decrease in NFUE (Figure 5).

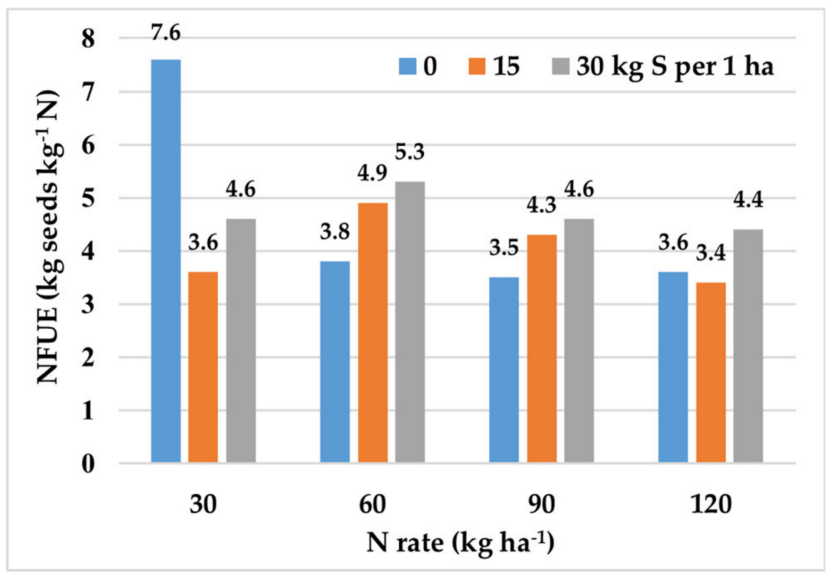

Figure 5. Nitrogen fertilizer use efficiency in treatments with different $S$ fertilization rates (across years).

Straw yield ranged from $1.24-1.80(2017,2018)$ to $3.40 \mathrm{Mg} \mathrm{ha}^{-1} \mathrm{DM}(2019)$ (Table 4). This parameter increased significantly up to the $\mathrm{N}$ rate of $120 \mathrm{~kg} \mathrm{~N} \mathrm{ha}^{-1}(33 \%)$ and the $\mathrm{S}$ rate of $30 \mathrm{~S} \mathrm{ha}^{-1}(14 \%)$ (Table 4), regardless of agroecological conditions (Table 2).

The content of $C$. abyssinica seeds in total harvested biomass (hulled seeds + straw) ranged from 35 to $48 \%$ (Table 4). Nitrogen rates of $\geq 60 \mathrm{~kg} \mathrm{ha}^{-1}$ had a negative impact on the ratio of seeds to straw (the harvest index decreased from $0.49-0.41$ to $0.31-37$ ) in years with average and above-average precipitation (2018 and 2019, respectively) (Figure 1). In the year with below-average precipitation (2017), N fertilization had no significant effect on the value of HI (Figure 4). The content of seeds in the total harvested biomass of $C$. abyssinica was not significantly affected by $\mathrm{S}$ fertilization levels (Table 2).

\subsection{Quality of Seeds and Oil}

Hulled crambe seeds contained 324-394 $\mathrm{g} \mathrm{kg}^{-1} \mathrm{DM}$ of crude fat and $208-238 \mathrm{~g} \mathrm{~kg}^{-1} \mathrm{DM}$ of total protein. Crude fat and total protein content were highest in the year with average precipitation (2018). In years with below-average (2017) or above-average (2019) precipitation, crude fat and total protein 
content was $15-18 \%$ and $10-12 \%$ lower, respectively. Nitrogen fertilization decreased the crude fat content of $C$. abyssinica seeds by $6 \%$ and increased total protein content by $11 \%$ (Table 5). Nitrogen rates up $60 \mathrm{~kg} \mathrm{ha}^{-1}$ decreased the synthesis of crude fat in seeds (Table 5), regardless of agroecological conditions (Table 2). On average, the total protein content of seeds increased up to the $\mathrm{N}$ rate of $90 \mathrm{~kg} \mathrm{~N} \mathrm{ha}^{-1}$ throughout the entire study (Table 5). However, total protein content was strongly influenced by the interaction between N rate and weather conditions. In the dry year of 2017, the total protein content of crambe seeds increased up to the $\mathrm{N}$ rate of $120 \mathrm{~kg} \mathrm{ha}^{-1}$. In years with average (2018) and above-average precipitation (2019), total protein content increased up to the $\mathrm{N}$ rates of 90 and $30 \mathrm{~kg} \mathrm{ha}^{-1}$, respectively (Figure 6). Sulfur rates up to $30 \mathrm{~kg} \mathrm{ha}^{-1}$ contributed to a $4-5 \%$ increase in the crude fat content of crambe seeds (Table 5), excluding in the year with above-average precipitation (2019) when the greatest increase in crude fat content was observed already in response to the $S$ rate of $15 \mathrm{~kg} \mathrm{ha}^{-1}$ (Figure 7). Sulfur fertilization had no significant effect on the total protein content of seeds, regardless of $\mathrm{N}$ rate or weather conditions (Table 2).

Table 5. Nutrient content of crambe seeds.

\begin{tabular}{|c|c|c|c|c|c|}
\hline Parameter & $\begin{array}{c}\text { Crude Fat } \\
\left(\mathrm{g} \mathrm{kg}^{-1} \mathrm{DM}\right)\end{array}$ & $\begin{array}{l}\text { Total Protein } \\
\left(\mathrm{g} \mathrm{kg}^{-1} \mathrm{DM}\right)\end{array}$ & $\begin{array}{l}\text { Crude Fiber } \\
\left(\mathrm{g} \mathrm{kg}^{-1} \mathrm{DM}\right)\end{array}$ & $\begin{array}{l}\text { Acid Detergent } \\
\text { Fiber (\%) }\end{array}$ & $\begin{array}{c}\text { Neutral Detergent } \\
\text { Fiber (\%) }\end{array}$ \\
\hline \multicolumn{6}{|l|}{ Year } \\
\hline 2018 & $393.6^{a}$ & $237.6^{\mathrm{a}}$ & $137.4^{\mathrm{a}}$ & 32.5 & $34.4^{\mathrm{b}}$ \\
\hline 2019 & $335.5^{b}$ & $208.2^{b}$ & $117.6^{b}$ & 32.6 & $44.2^{\mathrm{a}}$ \\
\hline 30 & $351.4^{\mathrm{ab}}$ & $215.9^{b c}$ & $123.1^{\mathrm{ab}}$ & 33.5 & $40.0^{b c}$ \\
\hline 60 & $346.6^{b}$ & $225.1^{\mathrm{ab}}$ & $129.7^{a b}$ & 32.4 & $41.4^{\mathrm{abc}}$ \\
\hline 90 & $345.7^{\mathrm{b}}$ & $229.2^{\mathrm{a}}$ & $134.8^{\mathrm{a}}$ & 32.6 & $42.2^{b c}$ \\
\hline 120 & $344.6^{\mathrm{b}}$ & $224.2^{\mathrm{ab}}$ & $134.5^{\mathrm{a}}$ & 30.7 & $44.2^{\mathrm{a}}$ \\
\hline \multicolumn{6}{|c|}{ Sulfur rate $\left(\mathrm{kg} \mathrm{ha}^{-1}\right)$, across years } \\
\hline
\end{tabular}

Means with the same letters do not differ significantly at $p \leq 0.05$ in Tukey's test. The absence of superscript letters indicates that the main effects or interactions were not statistically significant.

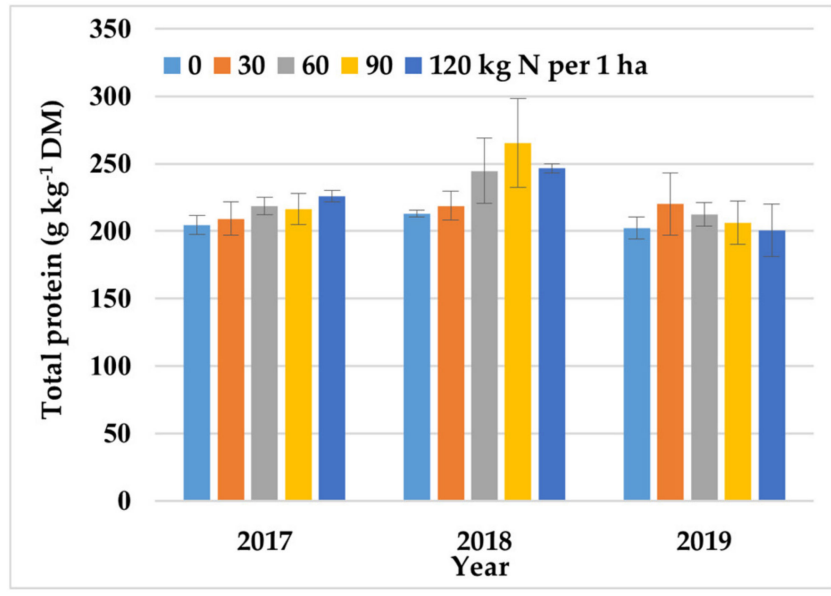

Figure 6. The effect of $\mathrm{N}$ fertilization on the total protein content of crambe seeds across growing seasons (2017-2017). Error bars represent the standard deviation. 


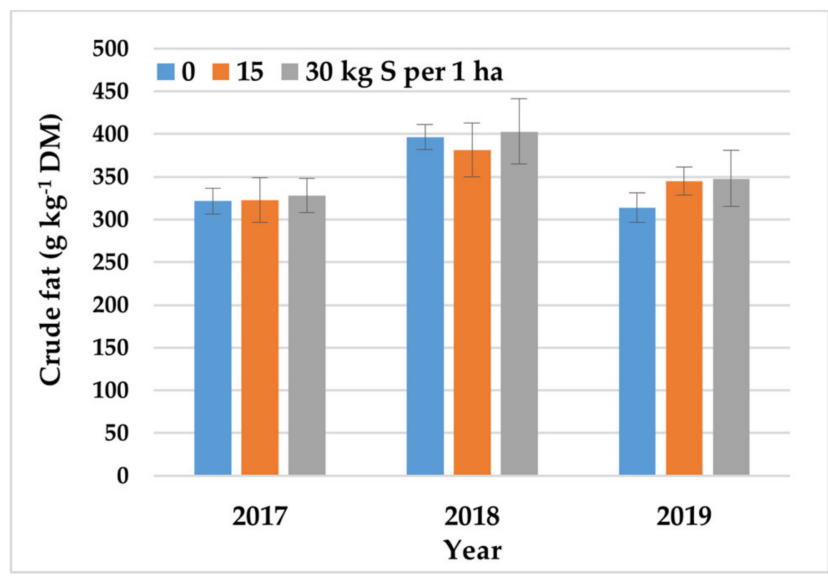

Figure 7. The effect of $S$ fertilization on the crude fat content of crambe seeds across growing seasons (2017-2019). Error bars represent the standard deviation.

The crude fiber content of crambe seeds ranged from 118 to $137 \mathrm{~g} \mathrm{~kg}^{-1} \mathrm{DM}$, and the proportions of ADF and NDF were determined at $33 \%$ and $43-45 \%$, respectively (Table 5). The crude fiber content of seeds was significantly lower (by 9-14\%) in the year with above-average precipitation (2019) in the treatment without $\mathrm{N}$ fertilization $\left(118 \mathrm{~g} \mathrm{~kg}^{-1} \mathrm{DM}\right)$. Nitrogen rates up to $90 \mathrm{~kg} \mathrm{ha}^{-1}$ increased the content of crude fiber and NDF by $14 \%$ and $4 \%$, respectively. Sulfur fertilization had no significant effect on the crude fiber content of seeds or the proportions of NDF and ADF (Table 2).

Erucic acid was the predominant component of Abyssinian oil, and it accounted for $57-65 \%$ of total fatty acids (Table 6). Abyssinian oil also contained considerable amounts of oleic acid (15-19\%) and linoleic acid (9-11\%) (Table 6). Abyssinian oil was most abundant in MUFAs which accounted for $79-82 \%$ of all fatty acids. Nitrogen fertilization increased the content of linoleic acid (from $9.2 \%$ to $9.8 \%$ ) and decreased the content of linolenic acid (from 7.2\% to 6.6\%) (Table 6). The proportions of SFAs, PUFAs, and MUFAs in Abyssinian oil were not significantly differentiated by $\mathrm{N}$ rate (Table 2). Sulfur fertilization significantly decreased the content of linoleic acid in Abyssinian oil (Table 6), but had no effect on the concentrations of the remaining FAs or the proportions of SFAs, MUFAs, or PUFAs (Table 2).

Table 6. Fatty acid composition of crambe oil (\%).

\begin{tabular}{|c|c|c|c|c|c|c|c|c|c|c|}
\hline Parameter & $\mathrm{C}_{16}$ & $\mathrm{C}_{18}$ & $\mathrm{C}_{18: 1}$ & $\mathrm{C}_{18: 2}$ & $\mathrm{C}_{18: 3}$ & $C_{20: 1}$ & $\mathrm{C}_{22: 1}$ & SFAs & MUFAs & PUFAs \\
\hline \multicolumn{11}{|l|}{ Year } \\
\hline 2017 & $2.0^{\mathrm{a}}$ & 0.7 & $18.7^{\mathrm{a}}$ & $10.8^{\mathrm{a}}$ & 7.2 & $3.7^{\mathrm{a}}$ & $56.8^{\mathrm{b}}$ & 2.7 & $79.3^{b}$ & $18.0^{\mathrm{a}}$ \\
\hline 2018 & $1.9^{a b}$ & 0.7 & $17.7^{\mathrm{a}}$ & $8.6^{\mathrm{b}}$ & 6.7 & $2.1^{\mathrm{b}}$ & $62.3^{a}$ & 2.6 & $82.0^{\mathrm{a}}$ & $15.3^{b}$ \\
\hline 2019 & $1.7^{\mathrm{b}}$ & 0.7 & $14.7^{\mathrm{b}}$ & $9.5^{\mathrm{b}}$ & 6.7 & $1.4^{\mathrm{c}}$ & $65.0^{\mathrm{a}}$ & 2.4 & $81.4^{\mathrm{a}}$ & $16.2^{b}$ \\
\hline \multicolumn{11}{|c|}{ Nitrogen rate $\left(\mathrm{kg} \mathrm{ha}^{-1}\right)$, across years } \\
\hline 0 & $1.6^{\mathrm{b}}$ & 0.7 & 17.3 & $9.2^{b}$ & $7.2^{\mathrm{a}}$ & 2.4 & 61.6 & $2.3^{b}$ & 81.3 & 16.4 \\
\hline 30 & $1.8^{\mathrm{ab}}$ & 0.6 & 17.3 & $9.6^{\mathrm{ab}}$ & $7.0^{\mathrm{ab}}$ & 2.4 & 61.3 & $2.4^{\mathrm{ab}}$ & 81.0 & 16.6 \\
\hline 60 & $2.1^{\mathrm{a}}$ & 0.7 & 17.2 & $9.8^{\mathrm{a}}$ & $6.9^{\mathrm{ab}}$ & 2.4 & 60.9 & $2.7^{\mathrm{a}}$ & 80.6 & 16.6 \\
\hline 90 & $2.1^{\mathrm{a}}$ & 0.7 & 16.9 & $9.8^{\mathrm{a}}$ & $6.7^{\mathrm{ab}}$ & 2.5 & 61.3 & $2.8^{\mathrm{a}}$ & 80.7 & 16.5 \\
\hline 120 & $2.02^{\mathrm{a}}$ & 0.7 & 16.9 & $9.7^{\mathrm{ab}}$ & $6.6^{\mathrm{b}}$ & 2.3 & 61.7 & $2.7^{a b}$ & 81.0 & 16.3 \\
\hline \multicolumn{11}{|c|}{ Sulfur rate $\left(\mathrm{kg} \mathrm{ha}^{-1}\right)$, across years } \\
\hline 0 & 1.8 & 0.7 & 17.1 & $9.6^{\mathrm{ab}}$ & 6.9 & 2.5 & 61.3 & 2.5 & 80.9 & 16.6 \\
\hline 15 & 1.9 & 0.7 & 17.3 & $9.7^{\mathrm{a}}$ & 6.8 & 2.4 & 61.1 & 2.6 & 80.8 & 16.5 \\
\hline 30 & 1.9 & 0.6 & 16.9 & $9.5^{\mathrm{b}}$ & 6.9 & 2.3 & 61.7 & 2.6 & 81.0 & 16.4 \\
\hline
\end{tabular}

Means with the same letters do not differ significantly at $p \leq 0.05$ in Tukey's test. The absence of superscript letters indicates that the main effects or interactions were not statistically significant. $\mathrm{C}_{16}$-palmitic acid; $\mathrm{C}_{18}$ - stearic acid; $C_{18: 1}$ —oleic acid; $C_{18: 2}$ - linoleic acid; $C_{18: 3}$ - linolenic acid; $C_{20: 1}$ - eicosanoic acid; $C_{22: 1}$ - erucic acid; $S F A$ —saturated fatty acids; MUFA - monounsaturated fatty acids; PUFA— polyunsaturated fatty acids. 


\section{Discussion}

\subsection{Biomass Yield}

In Europe, crambe yields range from 1 to $1.6 \mathrm{Mg} \mathrm{ha}^{-1}$ in regions with a subarctic climate [21], from 2 to $3 \mathrm{Mg} \mathrm{ha}^{-1}$ in humid continental and oceanic climates [14,22,25,92], and can reach 3-4 Mg ha ${ }^{-1}$ in the Mediterranean climate [16,23]. In NE Poland with a humid continental climate (Köppen classification), crambe yields were determined at $0.9-1.8 \mathrm{Mg} \mathrm{ha}^{-1}$ [38] (this study, Table 4) to $3.1 \mathrm{Mg} \mathrm{ha}^{-1}$ [25]. In the group of Brassica crops best suited for cultivation in Poland, C. abyssinica is characterized by high yield variation $(65 \%)$ next to camelina $(74 \%)$ and garden cress (Lepidium sativum L.) $(62 \%)$ [35]. Crambe yields reach 1.7-2.1 $\mathrm{Mg} \mathrm{ha}^{-1}$ in the humid subtropical climate of southern Brazil [26-28]. In the hot desert climate of Arizona, USA, crambe seed yields were determined at $1.7-2.9 \mathrm{Mg} \mathrm{ha}^{-1}$ [29]. Crambe seed yields range from 1.3 to $3.1 \mathrm{Mg} \mathrm{ha}^{-1}$ in the semiarid climate of Western Australia [30] (Table 7).

The harvest index of $C$. abyssinica was determined at $0.29-0.37$ by Fontana et al. [16] and Stolarski et al. [38], and it ranged from 0.39 to 0.48 in the work of Stolarski et al. [25] and in the present study (Table 4).

In the production of $C$. abyssinica, all agronomic requirements for the species, as well as adequate soil management and plant nutrition requirements, have to be met to achieve high and stable seed yields [54]. Detailed fertilization recommendations for the species discussed are not available in the literature, and the effect of fertilization on the development of crambe plants and seed yields is ambiguous in the existing research $[25,26,93]$.

Crambe has similar soil fertility requirements to mustards and rapeseed [54]. According to Endres and Schatz [52], around $50 \mathrm{~kg}$ of $\mathrm{N}$ is required to produce $1 \mathrm{Mg}$ of seeds and the corresponding amount of straw. In Brazil, crambe seed yields peaked in response to $\mathrm{N}$ rates of 40 [94] to $60-90 \mathrm{~kg} \mathrm{ha}^{-1}[27,93]$. In a study conducted by Cihacek and Gonzales [95] in North Dakota (northern USA), seed yield increased up to the $\mathrm{N}$ rate of $100 \mathrm{~kg} \mathrm{ha}^{-1}$. In the current study, seed yields continued to increase up to the $\mathrm{N}$ rate of $120 \mathrm{~kg} \mathrm{ha}^{-1}$, mainly due to an increase in the number of plants $\mathrm{m}^{-2}$ and seeds plant ${ }^{-1}$. In another study conducted in NE Poland, crambe seed yields increased up to the N rate of $80 \mathrm{~kg} \mathrm{ha}^{-1}$ due to an increase in the number of seeds plant ${ }^{-1}$ and TSW [96]. Stolarski et al. [25] reported high and stable crambe yields $\left(2.1 \mathrm{Mg} \mathrm{ha}^{-1}\right)$ in NE Poland in treatments without $\mathrm{N}$ fertilization where winter wheat was the preceding crop. In the present study, $\mathrm{N}$ fertilization did not increase the seed yield of C. abyssinica in the year with low precipitation.

In this study, the NFUE of crambe ranged from 2.1 to $5.9 \mathrm{~kg}$ seeds $\mathrm{kg}^{-1} \mathrm{~N}$, subject to precipitation levels. As expected, C. abyssinica yields decreased with a rise in $\mathrm{N}$ rate (from 5.3 to $3.8 \mathrm{~kg}$ hulled seeds $\mathrm{kg}^{-1} \mathrm{~N}$ ). Similar trends were reported in studies of C. sativa $[63,68]$ and other Brassica crops (B. juncea, B. napus and B. rapa canolas, and B. juncea and S. alba mustards) [61].

Oilseed crops of the family Brassicaceae have high $S$ requirements [81]. In soils with moderate levels of S (10-35 mg SO${ }_{4}^{2-} \mathrm{kg}^{-1}$ soil [97], seed yields peaked in response to $20-30 \mathrm{~kg} \mathrm{~S} \mathrm{ha}^{-1}$ in B. juncea (traditional and canola type cultivars), C. sativa, and C. abyssinica $[68,81,84,85,98] ; 40 \mathrm{~kg} \mathrm{~S} \mathrm{ha}^{-1}$ in B. napus (spring cultivars) and S. alba; and 40 to $80 \mathrm{~kg} \mathrm{Sha}^{-1}$ in B. napus (winter cultivars) $[81,83,99]$. The current study was conducted on Haplic Luvisol originating from boulder clay with moderate $\mathrm{SO}_{4}^{2-}$ levels, and crambe yields increased up to the $\mathrm{S}$ rate of $15 \mathrm{~kg} \mathrm{ha}^{-1}(5 \%)$, mainly due to the beneficial influence of $\mathrm{S}$ on TSW and, to a lesser degree, on the number of seeds plant ${ }^{-1}$. Szczebiot [96] also reported a $5 \%$ increase in crambe seed yields in response to the $S$ rate of $25 \mathrm{~kg} \mathrm{ha}^{-1}$ in NE Poland.

Sulfur fertilization plays a key role in the production of Brassica crops because it directly affects seed yield and yield components, and indirectly increases the efficiency of $\mathrm{N}$ fertilization $[68,100,101]$. In the present study, $\mathrm{S}$ fertilization increased NFUE when $\mathrm{N}$ was applied at rates higher than $30 \mathrm{~kg} \mathrm{~N} \mathrm{ha}^{-1}$, by $29-39 \%\left(60 \mathrm{~kg} \mathrm{~N} \mathrm{ha}^{-1}\right), 23-31 \%\left(90 \mathrm{~kg} \mathrm{~N} \mathrm{ha}^{-1}\right)$, and $22 \%\left(120 \mathrm{~kg} \mathrm{~N} \mathrm{ha}^{-1}\right)$. When $\mathrm{N}$ was applied at $30 \mathrm{~kg} \mathrm{ha}^{-1}, \mathrm{~S}$ fertilization caused a 1.7- to 2.1-fold decrease in NFUE. Similar trends were reported in other studies, where NFUE increased in response to $S$ fertilization, particularly at higher $\mathrm{N}$ rates, in the production of C. sativa [68,102-104], B. juncea and B. rapa [86], and S. alba [105]. 
Table 7. Crambe seed yield, seed protein, and oil content, as reported in the literature reviewed.

\begin{tabular}{|c|c|c|c|c|c|}
\hline Traits & Units & Crop & $\begin{array}{l}\text { Value } \\
\text { Range }\end{array}$ & Region & Reference \\
\hline \multirow[t]{6}{*}{ Yield } & \multirow[t]{6}{*}{$\mathrm{Mg} \mathrm{ha}^{-1}$} & \multirow[t]{6}{*}{ C. abyssinica } & $1.0-1.6$ & Europe, subarctic & [21] \\
\hline & & & $2.0-3.0$ & $\begin{array}{l}\text { Europe, humid } \\
\text { continental }\end{array}$ & {$[14,22,25,92]$} \\
\hline & & & $3.0-4.0$ & Europe, Mediterranean & {$[16,23]$} \\
\hline & & & $1.7-2.1$ & $\begin{array}{l}\text { Brazil (humid } \\
\text { subtropical) }\end{array}$ & [26-28] \\
\hline & & & $1.7-2.9$ & $\begin{array}{l}\text { USA, hot desert } \\
\text { (Arizona) }\end{array}$ & [29] \\
\hline & & & $1.3-3.1$ & Australia (semiarid) & [30] \\
\hline \multirow[t]{3}{*}{$\begin{array}{c}\text { Yield } \\
\text { variation }\end{array}$} & \multirow[t]{3}{*}{$\%$} & C. abyssinica & 65 & $\begin{array}{l}\text { Poland (humid } \\
\text { continental) }\end{array}$ & [35] \\
\hline & & L. sativum & 62 & Poland & [35] \\
\hline & & C. sativa & 74 & Poland & [35] \\
\hline \multirow[t]{2}{*}{$\begin{array}{l}\text { Seed } \\
\text { protein }\end{array}$} & \multirow[t]{2}{*}{$\mathrm{g} \mathrm{kg}^{-1} \mathrm{DM}$} & \multirow[t]{2}{*}{ C. abyssinica } & $189-218$ & $\begin{array}{l}\text { European Russian, } \\
\text { Poland }\end{array}$ & {$[36,37]$} \\
\hline & & & $208-238$ & Poland & this study \\
\hline \multirow[t]{4}{*}{ Seed fat } & \multirow[t]{4}{*}{$\mathrm{g} \mathrm{kg}^{-1} \mathrm{DM}$} & \multirow[t]{4}{*}{ C. abyssinica } & $360-300$ & Russia & [37] \\
\hline & & & $298-379$ & Poland & $\begin{array}{l}{[34-36,38]} \\
\text { this study }\end{array}$ \\
\hline & & & $260-340$ & $\begin{array}{c}\text { Portgual (Mediterranean } \\
\text { climate) }\end{array}$ & [39] \\
\hline & & & $345-365$ & $\begin{array}{l}\text { Brazil (humid } \\
\text { subtropical) }\end{array}$ & [26] \\
\hline
\end{tabular}

\subsection{Quality of Seeds and Oil}

The seeds produced by plants of the genus Crambe (L.) have numerous applications in food processing, feed, oleochemical, and petrochemical industries [106]. The species differ in oil content and the quantitative and qualitative composition of fatty acids. The oil of $C$. cordifolia (Steven) and C. maritima (L.) is a valuable source of oleic acid (28-31\%). Oleic acid content is twice lower in Abyssinian oil. The seeds of $C$. stevenianae (Rupr) and C. tatarica (Sebeok) contain three times more linoleic acid (25-26\%) than the seeds of C. abyssinica. Eicosanoic acid is present in the seeds of most Crambe species (15-16\%), excluding C. abyssinica. Crambe pinnatifida (R. Br) is the most abundant source of linolenic acid (9-10\%). Erucic acid concentrations are highest in Abyssinian oil (58\%), and they are more than twice lower in the remaining species of the genus Crambe [107]. The genus Crambe is composed of more than 30 species [108], and C. abyssinica has the highest economic importance [12]. Hulled seeds of $C$. abyssinica cultivars grown in Russia (Polet, Demetra, VIR 1, and VIR 2) contain $360-399 \mathrm{~g} \mathrm{~kg}^{-1}$ of crude fat [37]. The crude fat content of hulled seeds in crambe cultivars grown in Poland (cvs. Borowski, Indy, Prophet, and Galactica) ranges from 298 to $379 \mathrm{~g} \mathrm{~kg}^{-1}$ DM [34-36,38] (this study, Table 5). The crude fat content of crambe seeds (cv. FMS Brilhante) grown in Portugal (Mediterranean climate) was determined at 260-340 $\mathrm{g} \mathrm{kg}^{-1}$ DM [39]. The crude fat content of hulled crambe seeds harvested in the humid subtropical climates of southeastern Brazil (cv. FMS Brilhante) and southwestern China (cv. Meyer) ranged from 345 to $364 \mathrm{~g} \mathrm{~kg}^{-1}$ DM hulled seeds [17,26] (Table 7). Abyssinian oil is most abundant in erucic acid (52-65\%), followed by oleic acid (15-19\%), linoleic acid (9-11\%), and linolenic acid (4-7\%) [24,33,34] (this study, Table 6). The content of SFAs in Abyssinian oil does not exceed $9 \%[18,24,33,34]$ (this study, Table 6). The qualitative and quantitative composition of FAs in Abyssinian oil is a genetic trait, which is only slightly modified even under radically different agronomic and weather conditions [18,24,33,34] (this study, Table 6).

Hulled seeds of $C$. abyssinica cultivars grown in European Russia (Middle Volga Region) and Central Europe (Poland) accumulate 189-218 $\mathrm{g} \mathrm{kg}^{-1} \mathrm{DM}$ total protein [36,37]. In the Mediterranean Region, the total protein content of hulled C. abyssinica seeds was higher by $50-70 \mathrm{~g} \mathrm{~kg}^{-1} \mathrm{DM}$ [33]. 
In the current study, the total protein content of C. abyssinica seeds ranged from 208 to $238 \mathrm{~g} \mathrm{~kg}^{-1} \mathrm{DM}$ and was typical for colder regions with a humid continental climate.

Regardless of genetic factors that affect nutrient synthesis in the seeds of Brassica crops, nutrient levels can be modified by climatic and soil conditions, and agronomic management [81]. In the group of agronomic factors, $\mathrm{N}[68,72,102,103,105,109,110]$ and $\mathrm{S}$ fertilization $[68,81,111,112]$ play a key role in the biosynthesis of major nutrients and bioactive components in the seeds of oilseed crops of the family Brassicaceae.

Nitrogen influences the synthesis of reserve compounds that determine the protein and crude fat content of oilseed crops $[54,113]$. In most Brassica crops, $\mathrm{N}$ fertilization decreases the crude fat content and increases the total protein content of seeds. This trend was reported in B. napus [72] and other Brassica crops, including C. sativa [68,102,103,110], B. juncea [109], and S. alba [105]. Similar observations were made in this study, where $\mathrm{N}$ fertilization affected the qualitative and quantitative composition of fatty acids in C. abyssinica seeds. High rates of $\mathrm{N}$ fertilizer increased the content of linoleic acid and decreased the content of linolenic acid in Abyssinian oil. In a study by Chaves et al. [93], the protein and crude fat content of crambe seeds was not modified by increasing $\mathrm{N}$ rates.

Sulfur exerts varied effects on the crude fat and total protein content of Brassica seeds. In B. napus [114,115], C. sativa $[68,102,103,116]$, and other oilseed crops of the family Brassicaceae (B. napus, B. juncea, S. alba), the relationship between $\mathrm{S}$ fertilization and the crude fat and total protein content of seeds appears to be less obvious [81]. In the current study, S fertilization exerted a minor impact on the total protein and crude fiber content of $C$. abyssinica seeds. The crude fat content of crambe seeds increased with a rise in $S$ rate, and the strength of this association was determined by weather conditions. In the year with above-average precipitation, oil concentration in crambe seeds was highest after the application $15 \mathrm{~kg} \mathrm{~S} \mathrm{ha}^{-1}$. In the year with below-average precipitation, the crude fat content of seeds increased in response to the $S$ rate of $30 \mathrm{~kg} \mathrm{ha}^{-1}$. Sulfur fertilization caused a significant decrease in the content of linoleic acid in Abyssinian oil, but did not affect the proportions of the remaining fatty acids or the total content of SFAs, MUFAs, and PUFAs.

\section{Conclusions}

Nitrogen fertilization increased plant height, shoot diameter at the base, the number of productive branches, the number of plants $\mathrm{m}^{-2}$, and seeds plant ${ }^{-1}$. Sulfur fertilization improved TSW. The growth-promoting effects of $\mathrm{N}$ and $\mathrm{S}$ fertilization on $\mathrm{C}$. abyssinica were more pronounced in the year with above-average precipitation, from inflorescence emergence to fruit development. In NE Poland, the average seed yields of $C$. abyssinica ranged from $0.96 \mathrm{Mg} \mathrm{ha}^{-1}$ in the dry year, to $1.64 \mathrm{Mg} \mathrm{ha}^{-1}$ in the year with average precipitation, and $1.82 \mathrm{Mg} \mathrm{ha}^{-1}$ in the year with above-average precipitation. The response of crambe plants to $\mathrm{N}$ fertilization was determined by precipitation. The $\mathrm{N}$ rate of $120 \mathrm{~kg} \mathrm{ha}^{-1}$ delivered satisfactory results in years with average and above-average precipitation, whereas $\mathrm{N}$ fertilization was not effective in the dry year of the experiment. Nitrogen rates of $\geq 60 \mathrm{~kg} \mathrm{ha}^{-1}$ decreased the $\mathrm{HI}$ in years with average and above-average precipitation. Nitrogen fertilization decreased the crude fat content and increased the total protein and crude fiber content of $C$. abyssinica seeds. Crambe seed yields continued to increase up to the $S$ rate of $15 \mathrm{~kg} \mathrm{ha}^{-1}$, regardless of agroecological conditions in the experimental years. Sulfur fertilization was particularly effective when $\mathrm{N}$ was applied at $>30 \mathrm{~kg} \mathrm{ha}^{-1}(22-39 \%$ increase in NFUE). Sulfur increased the crude fat content, but did not affect the concentrations of the remaining nutrients in crambe seeds. Abyssinian oil was most abundant in erucic acid (57-65\%), and it also contained considerable amounts of oleic acid (15-19\%) and linoleic acid (9-11\%). Nitrogen fertilization increased the content of linoleic acid and decreased the content of linolenic acid, whereas S fertilization significantly decreased the content of linoleic acid in Abyssinian oil.

Author Contributions: Conceptualization, M.S. and K.J.; methodology, K.J.; software, M.S. and K.J.; validation, M.S. and K.J.; formal analysis, K.J.; investigation, K.J.; resources, M.S. and K.J.; data curation, D.Z., M.S. and K.J.; writing-original draft preparation, M.S. and K.J.; writing—review and editing, M.S. and K.J.; visualization, K.J.; 
supervision, M.S. and K.J.; project administration, K.J.; funding acquisition, K.J. All authors have read and agreed to the published version of the manuscript.

Funding: The results presented in this paper were obtained as part of a comprehensive study financed by the University of Warmia and Mazury in Olsztyn (grant No. 20.610.020-110). Project financially supported by Minister of Science and Higher Education in the range of the program entitled "Regional Initiative of Excellence" for the years 2019-2022, project No. 010/RID/2018/19, amount of funding 12,000,000 PLN.

Acknowledgments: The authors would like to thank the staff of the Agricultural Experiment Station in Bałcyny for technical support during the experiment.

Conflicts of Interest: The authors declare no conflict of interest.

\section{References}

1. Haslam, T.M.; Kunst, L. Extending the story of very-long-chain fatty acid elongation. Plant Sci. 2013, 210, 93-107. [CrossRef] [PubMed]

2. Zorn, K.; Oroz-Guinea, I.; Bornscheuer, U.T. Strategies for enriching erucic acid from Crambe abyssinica oil by improved Candida antarctica lipase A variants. Process Biochem. 2019, 79, 65-73. [CrossRef]

3. Dyer, J.M.; Stymne, S.; Green, A.G.; Carlsson, A.S. High-value oils from plants. Plant J. 2008, 54, 640-655. [CrossRef] [PubMed]

4. Zanetti, F.; Vamerali, T.; Bona, S.; Mosca, G. Can we "cultivate" erucic acid in southern Europe? Ital. J. Agron. 2006, 1, 3-10. [CrossRef]

5. Li, X.; van Loo, E.N.; Gruber, J.; Fan, J.; Guan, R.; Frentzen, F.; Stymne, S.; Zhu, L.-H. Development of ultra-high erucic acid oil in the industrial oil crop Crambe abyssinica. Plant Biotechnol. J. 2012, 10, 862-870. [CrossRef]

6. Warner, D.J.; Lewis, K.A. Evaluation of the risks of contaminating low erucic acid rapeseed with high erucic rapeseed and identification of mitigation strategies. Agriculture 2019, 9, 190. [CrossRef]

7. FitzJohn, R.G.; Armstrong, T.T.; Newstrom-Lloyd, L.E.; Wilton, A.D.; Cochrane, M. Hybridisation within Brassica and allied genera: Evaluation of potential for transgene escape. Euphytica 2007, 158, $209-230$. [CrossRef]

8. Carlsson, A.S.; Zhu, L.H.; Andersson, M.; Hofvander, P. Platform crops amenable to genetic engineering-a requirement for successful production of bio-industrial oils through genetic engineering. Biocatal. Agric. Biotechnol. 2014, 3, 58-64. [CrossRef]

9. Kumar, A.; Sharma, A.; Upadhyaya, K. Vegetable oil: Nutritional and industrial perspective. Curr. Genom. 2016, 17, 230-240. [CrossRef]

10. Zhu, L.H. Crambe (Crambe abyssinica). In Industrial Oil Crops, 1st ed.; McKeon, T.A., Hayes, D.G., Hildebrand, D.F., Weselake, R.J., Eds.; Academic Press and AOCS Press; Elsevier Inc: Urbana, IL, USA, 2016; pp. 195-205.

11. Nath, U.K.; Wilmer, J.A.; Wallington, E.J.; Becker, H.C.; Möllers, C. Increasing erucic acid content through combination of endogenous low polyunsaturated fatty acids alleles with $L d-L P A A T+B n-f a e 1$ transgenes in rapeseed (Brassica napus L.). Appl. Genet. 2009, 118, 765-773. [CrossRef]

12. Warwick, S.I.; Gugel, R.K. Genetic variation in the Crambe abyssinica-C. hispanica-C. glabrata complex. Genet. Resour. Crop Ev. 2003, 50, 291-305. [CrossRef]

13. Oyen, L.P.A. Crambe hispanica L. In Plant resources of tropical Africa 14. Vegetable Oils; van der Vossen, H.A.M., Mkamilo, G.S., Eds.; PROTA Foundation; Backhuys Publishers: Wageningen, The Netherlands, 2007; pp. 65-68.

14. Mastebroek, H.D.; Lange, W. Progress in a crambe cross breeding programme. Ind. Crop. Prod. 1997, 6, 221-227. [CrossRef]

15. Oplinger, E.S.; Oelke, E.A.; Kaminski, A.R.; Putnam, D.H.; Teynor, T.M.; Doll, J.D.; Kelling, K.; Durgan, B.; Noetzel, D. Crambe. In Aternative Field Crops Manual; University of Wiscounsin Cooperative Extension Service: Madison, WI, USA, 1991.

16. Fontana, F.; Lazzeri, L.; Malaguti, L.; Galletti, S. Agronomic characterization of some Crambe abyssinica genotypes in a locality of the Po Valley. Eur. J. Agron. 1998, 9, 117-126. [CrossRef]

17. Wang, Y.P.; Tang, J.S.; Chu, C.Q.; Tian, J. A preliminary study on the introduction and cultivation of Crambe abyssinica in China, an oil plant for industrial uses. Ind. Crop. Prod. 2000, 12, 47-52. [CrossRef] 
18. Lalas, S.; Gortzi, O.; Athanasiadis, V.; Dourtoglou, E.; Dourtoglou, V. Full characterisation of Crambe abyssinica Hochst. seed oil. J. Am. Oil. Chem. Soc. 2012, 89, 2253-2258. [CrossRef]

19. Von Cossel, M.; Lewandowski, I.; Elbersen, B.; Staritsky, I.; Van Eupen, M.; Iqbal, Y.; Mantel, S.; Scordia, D.; Testa, G.; Cosentino, S.L.; et al. Marginal agricultural land low-input systems for biomass production. Energies 2019, 12, 3123. [CrossRef]

20. Ionov, M.; Yuldasheva, N.; Ulchenko, N.; Glushenkova, A.I.; Heuer, B. Growth, development and yield of Crambe abyssinica under saline irrigation in the greenhouse. J. Agron. Crop Sci. 2013, 199, 331-339. [CrossRef]

21. Falasca, S.L.; Flores, N.; Lamas, M.C.; Carballo, S.M.; Anschau, A. Crambe abyssinica: An almost unknown crop with a promissory future to produce biodiesel in Argentina. Int. J. Hydrog. Energy 2010, 35, 5808-5812. [CrossRef]

22. Vollmann, J.; Ruckenbauer, P. Agronomic performance and oil quality of crambe as affected by genotype and environment. Bodenkultur 1993, 44, 335-343.

23. Fila, G.; Fontana, F.; Maestrini, C.; Bellocchi, G. Field evaluation of crambe cultivars in northern Italy. In Proceedings of the VII Congress European Society for Agronomy, Córdoba, Spain, 15-18 July 2002; pp. 179-180.

24. Zanetti, F.; Scordia, D.; Vamerali, T.; Copani, V.; Dal Cortivo, C.; Mosca, G. Crambe abyssinica a non-food crop with potential for the Mediterranean climate: Insights on productive performances and root growth. Ind. Crop. Prod. 2016, 90, 152-160. [CrossRef]

25. Stolarski, M.J.; Krzyżaniak, M.; Tworkowski, J.; Załuski, D.; Kwiatkowski, J.; Szczukowski, S. Camelina and crambe production-Energy efficiency indices depending on nitrogen fertilizer application. Ind. Crop. Prod. 2019, 137, 386-395. [CrossRef]

26. Soratto, R.P.; Sousa-Schlickg, D.; Fernandes, A.M.; Souza, E.F.C. Effect of fertilization at sowing on nutrition and yield of crambe in second season. Rev. Bras. Ciênc. Solo 2003, 37, 658-666. [CrossRef]

27. Lunelli, I.E.; Secco, D.; de Marins, A.C.; Rosa, H.A.; Santos, R.F.; Borsoi, A.; Veloso, G.; Bariccatti, R.A.; de Souza, S.N.M.; da Silva, T.R.B. Effects of nutritional arrangements of NPK on the yield of grains and crambe oil cultivation. Afr. J. Agric. Res. 2013, 8, 2048-2052.

28. Viana, O.H.; Santos, R.F.; de Oliveira, R.C.; Secco, D.; de Souza, S.N.M.; Tokura, L.K.; Benetoli da Silva, T.R.; Gurgacz, F. Crambe (Crambe abyssinica H.) development and productivity under different sowing densities. Aust. J. Crop Sci. 2015, 9, 690-695.

29. Adamsen, F.J.; Coffelt, T.A. Planting date effects on flowering, seed yield, and oil content of rape and crambe cultivars. Ind. Crop. Prod. 2005, 21, 293-307. [CrossRef]

30. Francis, C.M.; Campbell, M.C. New High Quality Oil Seed Crops for Temperate and Tropical Australia; Report 03/045, 2003; Rural Industries Research and Development Corporation: Canberra, Australia, 2003.

31. Carlson, K.D.; Tookey, H.L. Crambe meal as a protein source for feeds. J. Am. Oil. Chem. Soc. 1983, 60, 1979-1985. [CrossRef]

32. Van Soest, L.J.M. New Crop Development in Europe. In New Crops; Janick, J., Simmon, J.E., Eds.; John Wiley \& Sons, Ltd.: New York, NY, USA, 1993; pp. 30-38.

33. Lazzeri, L.; Leoni, O.; Conte, L.S.; Palmieri, S. Some technological characteristics and potential uses of Crambe abyssinica products. Ind. Crops Prod. 1994, 3, 103-112. [CrossRef]

34. Zadernowski, R.; Budzyński, W.S.; Nowak-Polakowska, H.; Rashed, A.A.; Jankowski, K.J. Effect of fertilisation on the composition of lipids from false flax (Camelina sativa L. Cr.) and crambe (Crambe abissinica Hochst.). Rośliny Oleiste-Oilseed Crop. 1999, 20, 503-510. (In Polish)

35. Toboła, P.; Muśnicki, C. Yielding variability of spring sown oilseed crops of cruciferous family. Rośliny Oleiste-Oilseed Crop. 1999, 10, 93-100. (In Polish)

36. Kulig, B.; Pisulewska, E. Fruit yield and chemical composition of crambe genotypes (Crambe abyssinica Hochst.) as affected by the growing seasons. Rośliny Oleiste-Oilseed Crop. 2000, 21, 631-639. (In Polish)

37. Kshnikatkina, A.N.; Krylova, D.S. Cultivation technology of crambe for seeds with application of microelements and growth regulators. Vestn. Ulyanovsk State Agric. Acad. 2016, 4, 30-38. (In Russian) [CrossRef]

38. Stolarski, M.J.; Krzyżaniak, M.; Kwiatkowski, J.; Tworkowski, J.; Szczukowski, S. Energy and economic efficiency of camelina and crambe biomass production on a large-scale farm in north-eastern Poland. Energy 2018, 150, 770-780. [CrossRef] 
39. Costa, E.; Almeida, M.F.; Alvim-Ferraz, C.; Dias, J.M. Cultivation of Crambe abyssinica non-food crop in Portugal for bioenergy purposes: Agronomic and environmental assessment. Ind. Crops Prod. 2019, 139, 111501. [CrossRef]

40. Anderson, V.L.; Slanger, W.D.; Boyles, S.L.; Berg, P.T. Crambe meal is equivalent to soybean meal for backgrounding and finishing beef steers. J. Anim. Sci. 1993, 71, 2608-2613. [CrossRef] [PubMed]

41. Carlson, K.D.; Baker, E.C.; Mustakas, G.C. Processing of crambe abyssinica seed in commercial extraction facilities. J. Am. Oil Chem. Soc. 1985, 62, 897-905. [CrossRef]

42. Ítavo, L.C.V.; de Souza, A.D.V.; Fávaro, S.P.; Ítavo, C.C.B.F.; Petit, H.V.; Dias, A.M.; Morais, M.G.; Coelho, R.G.; Reis, F.A.; Costa, J.A.A.; et al. Intake, digestibility, performance, carcass characteristics and meat quality of lambs fed different levels of crambe meal in the diet. Anim. Feed Sci. Tech. 2016, 216, 40-48. [CrossRef]

43. Ítavo, L.C.V.; Soares, C.M.; Ítavo, C.C.B.F.; Dias, A.M.; Petit, H.V.; Leal, E.S.; de Souza, A.D.V. Calorimetry, chemical composition and in vitro digestibility of oilseeds. Food Chem. 2015, 185, 219-225. [CrossRef]

44. Tripathi, M.K.; Mishra, A.S. Glucosinolates in animal nutrition: A review. Anim. Feed Sci. Technol. 2007, 132, 1-27. [CrossRef]

45. Price, W.D.; Lovell, R.A.; McChesney, D.G. Naturally occurring toxins in deedstuffs: Center for veterinary medicine perspective. J. Anim. Sci. 1993, 71, 2556-2562. [CrossRef]

46. Righini, D.; Zanetti, F.; Monti, A. The bio-based economy can serve as the springboard for camelina and crambe to quit the limbo. Ocl Oilseeds Fats Crop. Lipids 2016, 23, D504. [CrossRef]

47. Hu, J.; Deng, Z.; Wang, B.; Zhi, Y.; Pei, B.; Zhang, G.; Luo, M.; Huang, B.; Wu, W.; Huang, B. Influence of heavy metals on seed germination and early seedling growth in Crambe abyssinica, a potential industrial oil crop for phytoremediation. Am. J. Plant Sci. 2015, 6, 150-156. [CrossRef]

48. Anderson, M.D.; Peng, C.; Weissl, M.J. Crambe, Crambe abyssinica Hochst., as a flea beetle resistant crop (Coleoptera: Chrysomelidae). J. Econ. Entomol. 1992, 85, 594-600. [CrossRef]

49. Tsao, R.; Reuber, M.; Johnson, L.; Coats, J.R. Insecticidal toxicities of glucosinolate-containing extracts from crambe seeds. J. Agric. Entomol. 1996, 13, 109-120.

50. Kmec, P.; Weiss, M.J.; Milbrath, L.R.; Schatz, B.G.; Hanzel, J.; Hanson, B.K.; Eriksmoen, E.D. Growth analysis of crambe. Crop Sci. 1998, 38, 108-112. [CrossRef]

51. Martínez-Ballesta, M.; Moreno, D.; Carvajal, M. The physiological importance of glucosinolates on plant response to abiotic stress in Brassica. Int. J. Mol. Sci. 2013, 14, 11607-11625. [CrossRef] [PubMed]

52. Endres, G.; Schatz, B. Crambe Production, County Commissions, North Dakota State University Agriculture and University Extension. Department of Agriculture Cooperating, USA, 1993. Available online: https: //www.ag.ndsu.edu/crops/other-crops/crambe-a1010 (accessed on 29 June 2020).

53. Kurowski, T.P.; Jankowski, K.J. Sanitary state of crambe and spring false flax in relation to way of fertilization. Rośliny Oleiste-Oilseed Crop. 2003, 24, 477-488. (In Polish)

54. Bassegio, D.; Zanotto, M.D.; Santos, R.F.; Werncke, I.; Dias, P.P.; Olivo, M. Oilseed crop crambe as a source of renewable energy in Brazil. Renew. Sust. Energ. Rev. 2016, 66, 311-321. [CrossRef]

55. Allen, B.L.; Lenssen, A.W.; Sainju, U.M.; Caesar-TonThat, T.; Evans, R.G. Nitrogen use in durum and selected brassicaceae oilseeds in two-year rotations. Agron. J. 2014, 106, 821-830. [CrossRef]

56. Acharya, K.; Yan, G.; Berti, M. Can winter camelina, crambe, and brown mustard reduce soybean cyst nematode populations? Ind. Crops Prod. 2019, 140, 111637. [CrossRef]

57. Rahman, M.; Khatun, A.; Liu, L.; Bronwyn, J. Brassicaceae mustards: Traditional and agronomic uses in Australia and New Zealand. Molecules 2018, 23, 231. [CrossRef]

58. Krzyżaniak, M.; Stolarski, M.J. Life cycle assessment of camelina and crambe production for biorefinery and energy purposes. J. Clean. Prod. 2019, 237, 117755. [CrossRef]

59. Bates, P.D.; Stymne, S.; Ohlrogge, J. Biochemical pathways in seed oil synthesis. Curr. Opin. Plant Biol. 2013, 16, 358-364. [CrossRef] [PubMed]

60. Masclaux-Daubresse, C.; Daniel-Vedele, F.; Dechorgnat, J.; Chardon, F.; Gaufichon, L.; Suzuki, A. Nitrogen uptake, assimilation and remobilization in plants: Challenges for sustainable and productive agriculture. Ann. Bot. 2010, 105, 1141-1157. [CrossRef] [PubMed]

61. Gan, Y.; Malhi, S.S.; Brandt, S.; Katepa-Mupondwa, F.; Stevenson, C. Nitrogen use efficiency and nitrogen uptake of juncea canola under diverse environments. Agron. J. 2008, 100, 285-295. [CrossRef]

62. Johnson, J.M.; Gesch, R.W. Calendula and camelina response to nitrogen fertility. Ind. Crop. Prod. 2013, 43, 684-691. [CrossRef] 
63. Malhi, S.S.; Johnson, E.N.; Hall, L.M.; May, W.E.; Phelps, S.; Nybo, B. Effect of nitrogen fertilizer application on seed yield, N uptake, and seed quality of Camelina sativa. Can. J. Soil Sci. 2014, 94, 35-47. [CrossRef]

64. Rasmussen, I.S.; Dresbøll, D.B.; Thorup-Kristensen, K. Winter wheat cultivars and nitrogen (N) fertilization-effects on root growth, $\mathrm{N}$ uptake efficiency and $\mathrm{N}$ use efficiency. Eur. J. Agron. 2015, 68, 38-49. [CrossRef]

65. Savin, R.; Sadras, V.O.; Slafer, G.A. Benchmarking nitrogen utilisation efficiency in wheat for Mediterranean and non-Mediterranean European regions. Field Crop. Res. 2019, 241, 107573. [CrossRef]

66. Grzebisz, W. Oilseed crops. In Crop Fertilization Methods Physiology of Crop Yields. Part 1. Oilseed Crops, Root Vegetables and Legumes; Grzebisz, W., Ed.; PWRiL: Poznań, Poland, 2011; pp. 50-135. (In Polish)

67. Berti, M.; Gesch, R.; Eynck, C.; Anderson, J.; Cermak, S. Camelina uses, genetics, genomics, production, and management. Ind. Crop. Prod. 2016, 94, 690-710. [CrossRef]

68. Jankowski, K.J.; Sokólski, M.; Kordan, B. Camelina: Yield and quality response to nitrogen and sulfur fertilization in Poland. Ind. Crop. Prod. 2019, 141, 111776. [CrossRef]

69. Jankowski, K.J.; Załuski, D.; Sokólski, M. Canola-quality white mustard: Agronomic management and seed yield. Ind. Crop. Prod. 2020, 145, 112138. [CrossRef]

70. Shirzadegan, M.; Röbbelen, G. Influence of seed color and hull proportion on quality properties of seeds in Brassica napus L. FetteSeifenAnstrichm. 1985, 87, 235-237. [CrossRef]

71. Nesi, N.; Delourme, R.; Brégeon, M.; Falentin, C.; Renard, M. Genetic and molecular approaches to improve nutritional value of Brassica napus L. seed. C. R. Biol. 2008, 331, 763-771. [CrossRef] [PubMed]

72. Narits, L. Effect of nitrogen rate and application time to yield and quality of winter oilseed rape (Brassica napus L. var. oleifera subvar. biennis). Agron. Res. 2010, 8, 671-686.

73. Cheema, M.A.; Saleem, M.F.; Muhammad, N.; Wahid, M.A.; Baber, B.H. Impact of rate and timing of nitrogen application on yield and quality of canola (Brassica napus L.). Pak. J. Bot. 2010, 42, 1723-1731.

74. Zhao, F.; Evans, E.J.; Bilsborrow, P.E.; Syers, J.K. Influence of sulphur and nitrogen on seed yield and quality of low glucosinolate oilseed rape (Brassica napus L). J. Sci. Food Agric. 1993, 63, 29-37. [CrossRef]

75. Noctor, G.; Gomez, L.; Vanacker, H.; Foyer, C.H. Interactions between biosynthesis, compartmentation and transport in the control of glutathione homeostasis and signaling. J. Exp. Bot. 2002, 53, 1283-1304. [CrossRef]

76. Nazar, R.; Iqbal, N.; Masood, A.; Syeed, S.; Khan, N.A. Understanding the significance of sulfur in improving salinity tolerance in plants. Environ. Exper. Bot. 2011, 70, 80-87. [CrossRef]

77. Anderson, J.W. Sulfur metabolism in plants. In The Biochemistry of Plants; Miflin, B.J., Lea, P.J., Eds.; Academic Press: San Diego, CA, USA, 1990; Volume 16, pp. 327-381.

78. Blake-Kalff, M.M.; Harrison, K.R.; Hawkesford, M.J.; Zhao, F.J.; McGrath, S.P. Distribution of sulfur within oilseed rape leaves in response to sulfur deficiency during vegetative growth. Plant Physiol. 1998, 118, 1337-1344. [CrossRef] [PubMed]

79. Zukalová, H.; Vasak, J. The role and effects of glucosinolates of Brassica species-a review. Rostl. Výroba 2002, 48, 175-180.

80. Watkinson, J.H.; Bolan, N.S. Modeling the rate of elemental sulfur oxidation in soils. In Sulfur in the Environment; Maynard, D.G., Dekker, M., Eds.; Madison Avenue: New York, NY, USA, 1998; pp. 135-172.

81. Jankowski, K.J.; Budzyński, W.S.; Kijewski, Ł.; Zając, T. Biomass quality of Brassica oilseed crops in response to sulfur fertilization. Agron. J. 2015, 107, 1377-1391. [CrossRef]

82. Bebkiewicz, K.; Dębski, B.; Chłopek, Z.; Doberska, A.; Kanafa, M.; Kargulewicz, I.; Olecka, A.; Rutkowski, J.; Skośkiewicz, J.; Waśniewska, S.; et al. Submission under the UN ECE Convention on Long-range Transboundary Air Pollution and the Directive (EU) 2016/2284. In Poland's Informative Inventory Report 2019; National Centre for Emissions Management, at The Institute of Environmental Protection-National Research Institute: Warsaw, Poland, 2019; Available online: https://www.kobize.pl/uploads/materialy/materialy_do_ pobrania/krajowa_inwentaryzacja_emisji/IIR_2019_Poland.pdf (accessed on 27 June 2020).

83. Jankowski, K.J.; Kijewski, Ł.; Groth, D.; Skwierawska, M.; Budzyński, W.S. The effect of sulfur fertilization on macronutrient concentrations in the post-harvest biomass of rapeseed (Brassica napus L. ssp. oleifera Metzg). J. Elem. 2015, 20, 585-597. [CrossRef]

84. Jankowski, K.J.; Krzebietke, S.; Budzyński, W.S. The effect of sulphur fertilization on macronutrient concentrations in the post-harvest biomass of mustard. Plant Soil Environ. 2015, 61, 266-272.

85. Ropelewska, E.; Jankowski, K.J. Effect of sulfur fertilization on the physical and chemical properties of crambe (Crambe abyssinica Hochst ex R.E. Fries) seeds. Oilseeds Fats Crop. Lipids 2020, 27, 18. [CrossRef] 
86. Ahmad, G.; Jan, A.; Arif, M.; Jan, M.T.; Khattak, R.A. Influence of nitrogen and sulfur fertilization on quality of canola (Brassica napus L.) under rainfed conditions. J. Zhejiang Univ. Sci. 2007, 8, 731-737. [CrossRef]

87. Brosnan, J.T.; Brosnan, M.E. The sulfur-containing amino acids: An overview. J. Nutr. 2006, 136, 1636-1640. [CrossRef]

88. Meier, U. Growth Stages of Mono- and Dicotyledonous Plants: BBCH Monograph; Julius Kühn-Institut: Quedlinburg, Germany, 2018. Available online: https://www.juliuskuehn.de/media/Veroeffentlichungen/ bbch\%20epaper\%20en/page.pdf (accessed on 28 June 2020).

89. IUSS Working Group WRB. World Reference Base for Soil Resources, 2nd ed.; World Soil Resources Report No. 103; FAO: Rome, Italy, 2006; p. 132.

90. Solis, A.; Vidal, I.; Paulino, L.; Johnson, B.L.; Berti, M.T. Camelina seed yield response to nitrogen, sulfur, and phosphorus fertilizer in South Central Chile. Ind. Crop. Prod. 2013, 44, 132-138. [CrossRef]

91. STATSOFT INC. Statistica (Data Analysis Software System), 10th ed.; STATSOFT INC, 2011. Available online: http:/www.statsoft.com (accessed on 20 May 2020).

92. Prakhova, T.; Smirnov, A.A.; Gushchina, V.A.; Kukharev, O.N. Agrobiological basis for formation of Crambe Abyssinica agrocoenosis in conditions of Middle Volga. Res. J. Pharm. Biol. Chem. Sci. 2018, 9, 2168-2172.

93. Chaves, L.H.G.; Ledur, E.O.; Fernandes, J.D.; de Brito Chaves, I. Development and production of crambe (Crambe abyssinica) under different nitrogen and phosphate fertilizers. Aust. J. Crop Sci. 2015, 9, 879-885.

94. Alves, J.M.; Leandro, W.M.; Neto, S.A.S.O.; Leão, A.K.M.; Alves, C.C.F.; Souchie, E.L. Effect of base saturation and nitrogen dose on cultivation of crambe. Afr. J. Agric. 2015, 10, 14-22.

95. Cihacek, L.J.; Gonzales, P.B. Soil fertility management for crambe production in North Dakota. In Alternative Crop and Alternative Crop Production Research; A Progress Report; Gardner, J., Ed.; North Dakota State University: Fargo, ND, USA, 1991; pp. 54-55.

96. Szczebiot, M. Effect of mineral fertilization on yielding of spring false flax and crambe. Rośliny Oleiste-Oilseed Crop. 2002, 23, 141-150.

97. Panak, H. Sulfur in soil, plants and fertilizers. In Agricultural Chemistry; Panak, H., Ed.; ART: Olsztyn, Poland, 1997; pp. 138-145. (In Polish)

98. Jankowski, K.J.; Budzyński, W.S.; Kijewski, Ł.; Klasa, A. Concentrations of copper, zinc and manganese in the roots, straw and oil cake of white mustard (Sinapis alba L.) and Indian mustard (Brassica juncea (L.) Czern. et Coss.) depending on sulfur fertilization. Plant Soil Environ. 2014, 60, 364-371.

99. Jankowski, K.; Kijewski, Ł.; Skwierawska, M.; Krzebietke, S.; Mackiewicz-Walec, E. The effect of sulfur fertilization on the concentrations of copper, zinc and manganese in the roots, straw and cake of rapeseed (Brassica napus L. ssp. oleifera Metzg). J. Elem. 2014, 19, 433-446. [CrossRef]

100. Schnug, E. Physiological functions and enviromental relevance of sulfur-containing secondary metabolites. In Sulfur Nutrition and Assimilation in Higher Plants; Regulatory Agricultural and Environmental Aspects; De Kok, L.J., Stulen, I., Rennenberg, H., Brunold, C., Rauser, W.E., Eds.; SPB Academic Publishing: The Hague, The Netherlands, 1993; pp. 179-190.

101. Fazili, I.S.; Jamal, A.; Ahmad, S.; Masoodi, M.; Khan, J.S.; Abdin, M.Z. Interactive effect of sulfur and nitrogen on nitrogen accumulation and harvest in oilseed crops differing in nitrogen assimilation potential. J. Plant Nutr. 2008, 31, 1203-1220. [CrossRef]

102. Lošák, T.; Hlušek, J.; Martinec, J.; Vollmann, J.; Peterka, J.; Filipčík, R.; Varga, L.; Ducsay, L.; Martensson, A. Effect of combined nitrogen and sulfur fertilization on yield and qualitative parameters of Camelina sativa [L.] Crtz. (false flax). Acta Agric. Scand. Sect. B Soil Plant Sci. 2011, 4, 313-321.

103. Jiang, Y.; Caldwell, C.D.; Falk, K.C.; Lada, R.R.; MacDonald, D. Camelina yield and quality response to combined nitrogen and sulfur. Agron. J. 2013, 105, 1847-1852. [CrossRef]

104. Wysocki, D.J.; Chastain, T.G.; Schillinger, W.F.; Guy, S.O.; Karow, R.S. Camelina: Seed yield response to applied nitrogen and sulfur. Field Crop. Res. 2013, 145, 60-66. [CrossRef]

105. Kovács, A.B.; Kincses, I.; Vágó, I.; Loch, J.; Filep, T. Effect of application of nitrogen and different nitrogen-sulfur ratios on the quality and quantity of mustard seed. Commun. Soil Sci. Plan. 2009, 40, 453-461. [CrossRef]

106. Samarappuli, D.; Zanetti, F.; Berzuini, S.; Bert, M.T. Crambe (Crambe abyssinica Hochst): A non-food oilseed crop with great potential: A review. Agronomy 2020, 10, 1380. [CrossRef]

107. Presnyakova, E.V.; Al'-Rabadi, E.E.; Semenova, E.F.; Shmaraeva, A.N. Fatty acid composition of crambe species. Izvestiya vysshikh uchebnykh zavedeniy. Povolzhskiy region. Yestestvennyye Nauk. 2018, 2, 3-16. (In Russian) 
108. Prina, A.O. The status of Crambe alutacea Hand.-Mazz. (Cruciferae, tribe Brassiceae). Fl. Medit. 1998, 1, 25-29.

109. Joshi, N.L.; Mali, P.C.; Saxena, A. Effect of nitrogen and sulphur application on yield and fatty acid composition of mustard (Brassica juncea L.) oil. J. Agron. Crop Sci. 1998, 180, 59-63. [CrossRef]

110. Czarnik, M.; Jarecki, W.; Bobrecka-Jamro, D. The effects of varied plant density and nitrogen fertilization on quantity and quality yield of Camelina sativa L. Emir. J. Food Agric. 2017, 29, 988-993.

111. Asare, E.; Scarisbrick, D.H. Rate of nitrogen and sulphur fertilizers on yield, yield components and seed quality of oilseed rape (Brassica napus L.). Field Crop. Res. 1995, 44, 41-46. [CrossRef]

112. Aires, A.; Rosa, E.; Carvalho, R. Effect of nitrogen and sulfur fertilization on glucosinolates in the leaves and roots of broccoli sprouts (Brassica oleracea var. italica). J. Sci. Food Agric. 2006, 86, 1512-1516. [CrossRef]

113. Castro, C.; Balla, A.; Castiglioni, V.B.R. Levels and methods of nitrogen supply for sunflower. Sci. Agric. 1999, 56, 827-833. [CrossRef]

114. Jankowski, K.J.; Budzyński, W.S.; Szymanowski, A. Effect of sulfur on the quality of winter rape seeds. J. Elem. 2008, 13, 521-534.

115. Šiaudinis, G.; Butkute, B. Responses of spring oilseed rape seed yield and quality to nitrogen and sulfur fertilization. Commun. Soil Sci. Plan. 2013, 44, 145-157. [CrossRef]

116. Ropelewska, E.; Jankowski, K.J. The physical and chemical properties of camelina (Camelina sativa (L.) Crantz) seeds subjected to sulfur fertilization. Oilseeds Fats Crop. Lipids 2020, 27, 46. [CrossRef]

(C) 2020 by the authors. Licensee MDPI, Basel, Switzerland. This article is an open access article distributed under the terms and conditions of the Creative Commons Attribution (CC BY) license (http://creativecommons.org/licenses/by/4.0/). 